Uili norden

Køn, uddannelse og befolkningsstrømme

Opsamling af tværnordiske indspil, erfaringer og praksiseksempler 

4 norden 



\section{Køn, uddannelse og befolkningsstrømme}

Opsamling af tværnordiske indspil, erfaringer og praksiseksempler

Kathrine Bjerg Bennike, Stine Thidemann Faber og

Helene Pristed Nielsen

TemaNord 2016:513 
Køn, uddannelse og befolkningsstrømme

Opsamling af tværnordiske indspil, erfaringer og praksiseksempler

Kathrine Bjerg Bennike, Stine Thidemann Faber og Helene Pristed Nielsen

ISBN 978-92-893-4501-9 (PRINT)

ISBN 978-92-893-4502-6 (PDF)

ISBN 978-92-893-4503-3 (EPUB)

http://dx.doi.org/10.6027/TN2016-513

TemaNord 2016:513

ISSN 0908-6692

(C) Nordisk Ministerråd 2016

Layout: Hanne Lebech

Omslagsfoto: ImageSelect

Tryk: Rosendahls-Schultz Grafisk

Printed in Denmark

Denne rapport er udgivet med finansiel støtte fra Nordisk Ministerråd. Indholdet i rapporten afspejler dog ikke nødvendigvis Nordisk Ministerråds synspunkter, meninger, holdninger eller anbefalinger.

\section{www.norden.org/nordpub}

\section{Det nordiske samarbejde}

Det nordiske samarbejde er en af verdens mest omfattende regionale samarbejdsformer. Samarbejdet omfatter Danmark, Finland, Island, Norge og Sverige samt Færøerne, Grønland og Åland.

Det nordiske samarbejde er både politisk, økonomisk og kulturelt forankret, og er en vigtig medspiller i det europæiske og internationale samarbejde. Det nordiske fællesskab arbejder for et stærkt Norden i et stærkt Europa.

Det nordiske samarbejde ønsker at styrke nordiske og regionale interesser og værdier i en global omverden. Fælles værdier landene imellem er med til at styrke Nordens position som en af verdens mest innovative og konkurrencedygtige regioner.

\section{Nordisk Ministerråd}

Ved Stranden 18

1061 København K

Telefon (+45) 33960200

www.norden.org 


\section{Indhold}

Resumé - DK

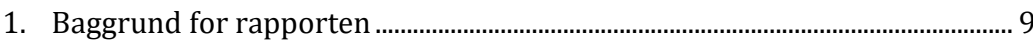

2. Tal og fakta om køn, uddannelse og befolkningsstrømme............................11

3. Hvorfor er det vigtigt at medtænke køn og ligestilling? ........................................21

4. Ligheder og forskelle mellem de nordiske lande ................................................23

5. Eksisterende forskning og faglitteratur - et sammendrag.............................25

5.1 De unge i yderområderne føler et stort pres for at forlade deres lokalsamfund

5.2 Det er ofte uddannelses- eller arbejdsrelateret, når unge (især kvinderne) flytter.

5.3 Stedet, hvor de unge bor, danner præmisserne for deres muligheder og valg i forhold til uddannelse

5.4 Stedet, hvor de unge bor, danner tillige præmisserne for engagement og lyst til læring ................................................................26

5.5 Den geografiske mobilitet er ofte koblet til social mobilitet.............27

5.6 Både det kønsopdelte uddannelsesvalg og det kønsopdelte arbejdsmarked er udtalt i Nordens yderområder ...................................28

5.7 De unge kvinder i yderområderne oplever ikke bare at have færre muligheder på de lokale arbejdsmarkeder, men også i det lokale foreningsliv, ved fritidsaktiviteter og i kulturelle udbud....................28

5.8 Den stærke kønssegregering af de nordiske arbejdsmarkeder forstærker de negative udviklingstendenser i yderområderne ......29

5.9 Yderområderne rummer potentielt iboende patriarkalske strukturer, der skubber de unge kvinder væk.

5.10 Nogle mænd i yderområderne bliver særligt ramt af de lokale arbejdsmarkeders omstrukturering og de ændrede levevilkår......29

5.11 I yderområderne bor også mænd, som har truffet bevidste valg som bliver boende, fordi de trives netop her.

6. Indspil til politiske beslutningstagere og andre myndigheder samt udvalgte

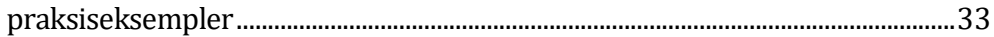

6.1 Tema: Begrænset adgang til uddannelse i yderområderne..............34

6.2 Tema: Omstrukturering af yderområdernes arbejdsmarkeder .....38

6.3 Tema: Kvinder finder livet i yderområderne mindre attraktivt...... 40

6.4 Tema: Arbejdsudbuddet er for snævert i yderområderne.................43

6.5 Tema: Yderområdernes stigma påvirker de unge af begge køn...... 44

Referencer...................................................................................................................... 49

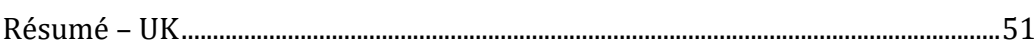





\section{Resumé - DK}

Under det danske formandskab for Nordisk Ministerråd i 2015 blev der sat fokus på udfordringer og gode praksiseksempler i relation til køn, uddannelse og befolkningsstrømme i yderområderne i hele Norden Norge, Danmark, Sverige, Finland, Island og de selvstyrende lande Grønland, Færøerne samt Åland. Denne opsamlingsrapport sammenfatter de resultater samt konklusioner, som er afdækket i den eksisterende nordiske forskning og faglitteratur på området samt præsenterer de erfaringer og faglige indspil, som kom frem på et seminar for vidensdeling for forskellige interessenter på tværs af Norden. Rapport giver således en komprimeret præsentation af den viden, der foreligger på området, og fungerer samtidig som et mere praksisorienteret inspirationskatalog til politiske beslutningstagere, andre myndigheder og aktører i forhold til en fremtidig indsats på området - lokalt, regionalt, nationalt og på tværs af Norden. 



\section{Baggrund for rapporten}

Under det danske formandskab for Nordisk Ministerråd blev der i 2015 sat fokus på udfordringer og gode praksiseksempler i relation til køn, uddannelse og befolkningsstrømme i yderområderne i hele Norden Norge, Danmark, Sverige, Finland, Island og de selvstyrende lande Grønland, Færøerne samt Åland.

Som led heri blev der udfærdiget en kortlægning over eksisterende forskning og faglitteratur på området samt afholdt et tværnordisk seminar d. 17. juni 2015 i Nuuk med deltagelse af bl.a. en række politiske aktører, embedsfolk samt repræsentanter fra forskellige nordiske uddannelses- og arbejdslivsorganisationer. I forbindelse med udarbejdelsen af kortlægningen og gennemførelsen af seminaret blev der taget kontakt til et bredt udvalg af nordiske forskere og andre aktører på området for at afdække viden og erfaringer fra de forskellige lande bedst muligt.

Ønsket om at sætte fokus på køn, uddannelse og befolkningsstrømme har været motiveret af, at Nordens yderområder alle er kendetegnet ved en række ensartede udfordringer; udfordringer som bl.a. omfatter "ændrede levevilkår, stagnerende eller negativ økonomisk udvikling, lav vækst, nedgang i antallet af arbejdspladser (især indenfor de traditionelle mandefag) samt ikke mindst affolkning og migration (især blandt kvinderne i yderområderne). Der er tale om udfordringer, som har stor betydning for de mennesker som bor $\mathrm{i}$ yderområderne, men også for områdernes langsigtede levedygtighed og deres sammenhængskraft" (Faber, Pristed Nielsen \& Bennike 2015: 19). I forbindelse med kortlægningsarbejdet og det afholdte seminar blev det bekræftet, at ovennævnte udfordringer har bevågenhed i hele Norden, hvilket understregede, at fælles dialog og erfaringsudveksling på tværs af de nordiske lande er befordrende.

Denne opsamlingsrapport sammenfatter de resultater samt konklusioner, som er afdækket i den eksisterende nordiske forskning og faglitteratur på området samt de erfaringer og faglige indspil, som er kommet frem undervejs i den fælles dialog faciliteret af Nordisk Ministerråd i 2015. Tanken er således, at denne rapport kan give en komprimeret præsentation af den viden, der foreligger på området, og samtidig fungere som et mere praksisorienteret inspirationsgrundlag 
for politiske beslutningstagere, andre myndigheder og aktører ( $\mathrm{fx}$ i den kommunale forvaltning, på uddannelsesinstitutionerne, på arbejdspladser, via interesseorganisationer, i fagbevægelserne, osv.) i forhold til en fremtidig indsats på området - lokalt, regionalt, nationalt og på tværs af Norden. For de læsere, som måtte have ønske om at få en bredere indføring i forskningen og litteraturen på området og et mere indgående kendskab til de bagvedliggende problematikker omkring køn, uddannelse og befolkningsstrømme henvises til kortlægningsrapporten "Sted, (U)lighed og Køn - En kortlægning af udfordringer og best practices i relation til køn, uddannelse og befolkningsstrømme i Nordens yderområder" (2015). ${ }^{1}$

${ }^{1}$ Kortlægningen om forskning og faglitteratur på området blev udarbejdet af Centre for Equality, Diversity and Gender (EDGE) på Aalborg Universitet og gennemført i perioden januar 2015 til maj 2015.

Kortlægningen findes i en henholdsvis engelsk- og dansksproget version. Begge ligger online tilgængeligt: Dansk version: "Sted, (U)lighed og Køn - En kortlægning af udfordringer og best practices i relation til køn, uddannelse og befolkningsstrømme i Nordens yderområder" (2015). Online tilgængelig her: http://dx.doi.org/10.6027/TN2015-557

Engelsk version: "Place, (In)Equality and Gender - A Mapping of Challenges and Best Practices in Relation to Gender, Education and Population Flows in Nordic Peripheral Areas" (2015). Online tilgængelig her: http://dx.doi.org/10.6027/TN2015-558 


\section{Tal og fakta om køn, uddannelse og befolkningsstrømme}

Dette afsnit giver en hurtig oversigt over de væsentligste forskelle og ligheder imellem de nordiske lande i forhold til aktuelle tal og fakta omkring køn, uddannelse og befolkningsstrømme i hele Norden.

Gennemgangen bygger overvejende på tal og oplysninger fra NordRegio (Nordic Centre for Spatial Development), der bl.a. producerer statistiske overblik over Nordens yderområder. NordRegio har udarbejdet og udgivet en række oversigtskort, som blandt andet viser netto-migrationen og den udadgående migrationen i yderområderne fordelt på køn, samt afbilder uddannelsestendenserne i Norden. Disse oversigtskort - hvoraf flere er gengivet på de næste sider - giver visuelt et overblik over situationen i Nordens yderområder, og de skildrer således hvor, der geografisk er særlige udfordringer.

Oversigtskortene illustrerer ligeledes, at der er tale om en meget koncentreret og mere eller mindre ensartet tendens i alle de nordiske lande, og dermed illustrerer de med tydelighed de forskellige udfordringer Norden står overfor, når det kommer til befolkningsstrømme og kønnede udviklingstendenser i yderområderne.

Vidste du at...

- De nordiske lande står overfor en række af de samme udfordringer, når det kommer til køn, uddannelse og befolkningsstrømme i yderområderne.

- Der er stor sammenhæng mellem et lokalområdes størrelse og dets kønssammensætning: des mindre et samfund, desto større et underskud af kvinder.

- Selvom både mænd og kvinder søger mod de større byer, er tendensen langt stærkere blandt kvinderne.

- Udviklingstendenserne i Nordens yderområder rummer en stærk kønsdimension, som ofte overses.

Kilde: Faber, Pristed Nielsen \& Bennike 2015. 
I forhold til befolkningstæthed og flyttemønstre viser kort 1, at tendensen til affolkning i yderområderne går igen i alle de nordiske lande. Den mørkeblå farve på kortet illustrerer befolkningstilvæksten i de større byer og bynære områder, mens yderområderne er kendetegnet ved den grå farve, som signalerer befolkningsnedgang. Kortet viser således "vækstområder", hvor stigningen af befolkningen tilsvarer ca. $80 \%$ af den samlede stigning i de sidste ti år. I forhold til Danmark, Finland og Sverige kan der identificeres to til tre vækstområder, mens der er flere vækstområder i Norge. I Island ses ca. $90 \%$ af befolkningstilvæksten i Reykjavik-området.

Figur 1: Kortet viser ændringer i befolkningen i Norden i perioden 2003-2013

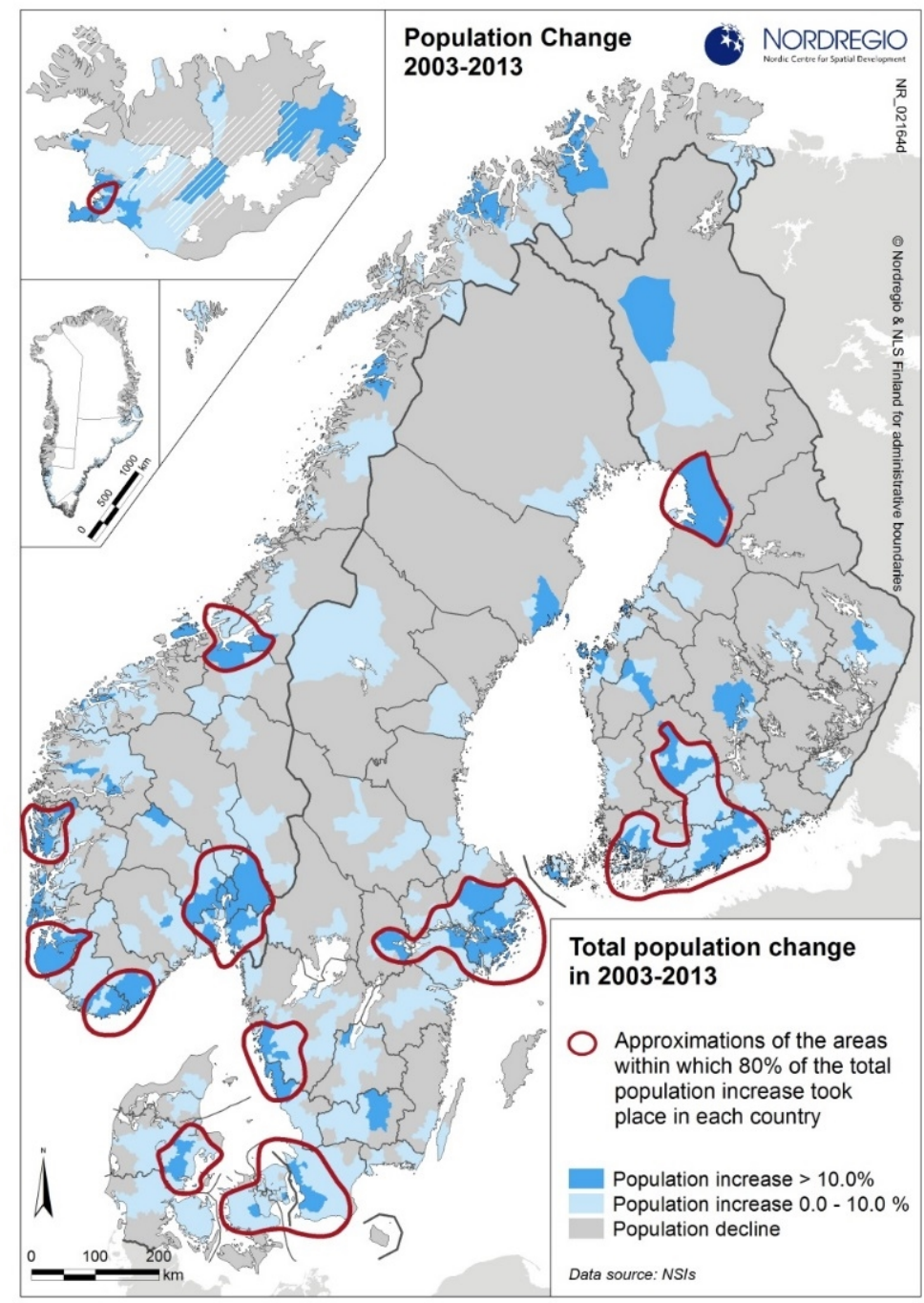

Kilde: NordRegio 2014.

Design: Johanna Roto. 
Kort 2 (på næste side) viser antallet af videregående uddannelsesinstitutioner pr. kommune (størrelse af cirkler - jo større cirkel, des flere uddannelsesinstitutioner), andelen af befolkningen med en videregående uddannelse pr. region (gul skygge - jo mørkere, des højere uddannelsesniveau), og andelen af kvinder med en videregående uddannelse pr. kommune hvori der er placeret en videregående uddannelsesinstitution (farven i cirklerne - og des rødere cirkel, des flere kvinder). I forhold til kommuner med højere læreanstalter viser kortet, at andelen af kvinder med en videregående uddannelse har en tendens til at være højere i hovedstadsområderne og i de større byer, hvilket visuelt indfanger, at kvinder i Norden i vid udstrækning flytter fra yderområderne og ind til byerne. Omvendt ses det, at de kommuner som kun har en enkelt uddannelsesinstitution placeret væk fra de større byer generelt har flere mænd med en videregående uddannelse. Altså eksisterer der tilsyneladende en synergieffekt, hvorved ikke blot placeringen af en enkelt uddannelsesinstitution, men det at flere placeres i nærheden af hinanden har betydning for kønssammensætningen i kommunen.

Den bagvedliggende årsagsforklaring er dog formodentlig, at urbaniseringsgraden (dvs. jo større en by der er tale om) påvirker både antallet af kvinder og antallet af placerede uddannelsesinstitutioner i opadgående retning. I Island, Grønland og på Færøerne har alle kommuner med højere antal uddannelsesinstitutioner et flertal af mænd med en videregående uddannelse. Baseret på konklusioner fra kortlægningen og fra seminaret er tendensen, som kortet også illustrerer, at mænd, såfremt der er uddannelsesmuligheder i nærområderne, gør brug af disse, hvorimod kvinderne ofte rejser for at tage en videregående uddannelse (for disse sidstnævnte tre lande gælder det især, at kvinderne flytter til andre lande i Norden for at tage en uddannelse) (se bl.a. Haagensen 2014 samt Rafnsdóttir 2010). I forhold til uddannelserne i Island, Grønland og på Færøerne, kan en yderligere faktor i forhold til kønsfordelingen forklares med, at en stor del af uddannelsesinstitutionerne har fokus på det maritime område, hvilket ofte tiltrækker flere mænd end kvinder. 
Figur 2: Kortet viser antallet af videregående uddannelsesinstitutioner pr. kommune, andelen af befolkningen med en videregående uddannelse pr. region, og andelen af kvinder med en videregående uddannelse pr. kommune hvori der er placeret en videregående uddannelsesinstitution

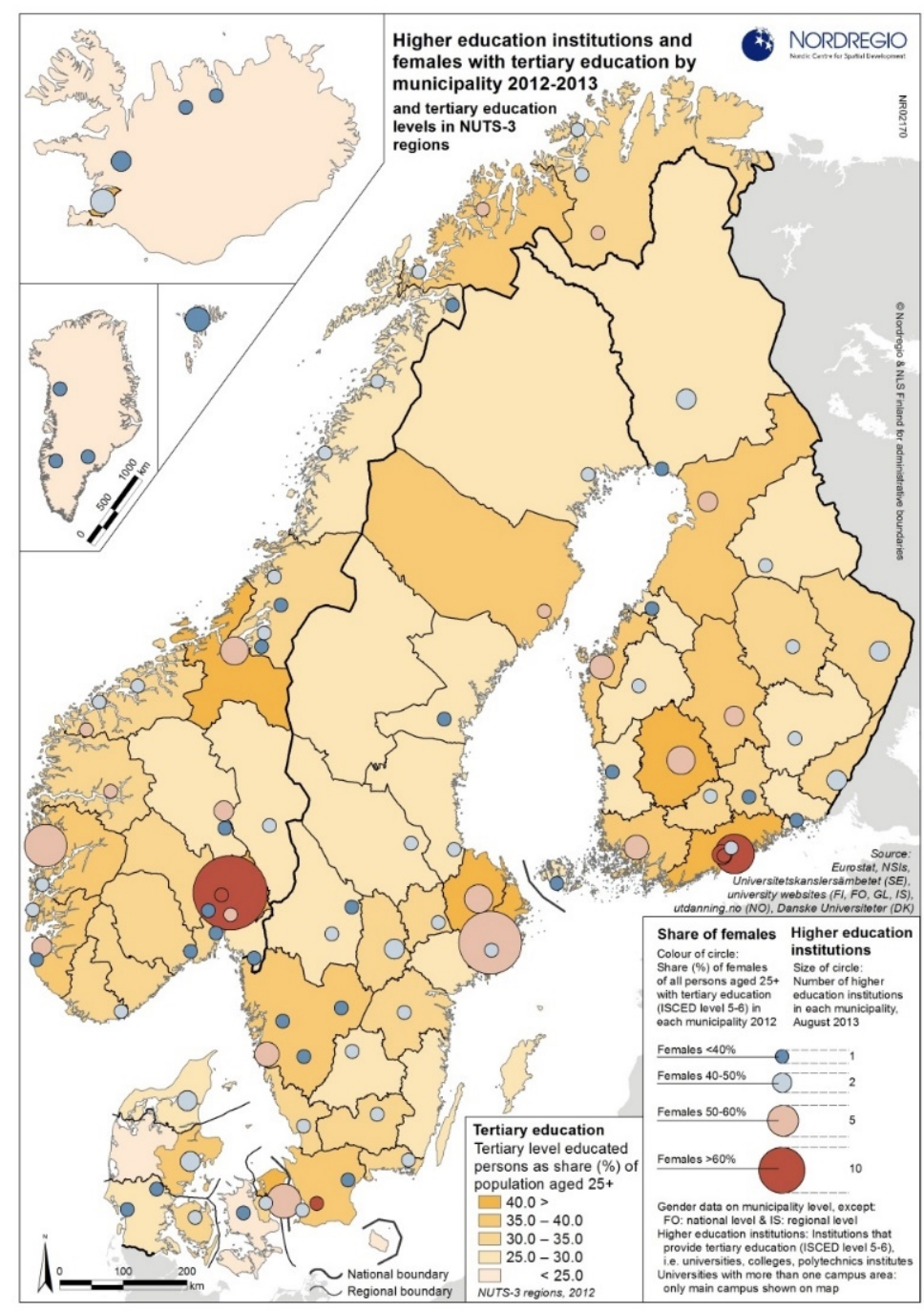

Kilde: NordRegio 2014.

Design: Linus Rispling. 
Når man ser på befolkningsstrømme i yderområderne, i form af til- og fraflytning, illustrerer kort 3 og 4, at der er en klar tendens til, at unge på tværs af Norden flytter fra yderområderne (kort 3), og at meget få familier med små børn flytter til disse områder, hvilket bevirker, at yderområderne bliver gradvist affolkede og befolkningsalderen stiger (kort 4).

Figur 3: Kortet viser fraflytning (out-migration) i Norden i perioden 2006-2010

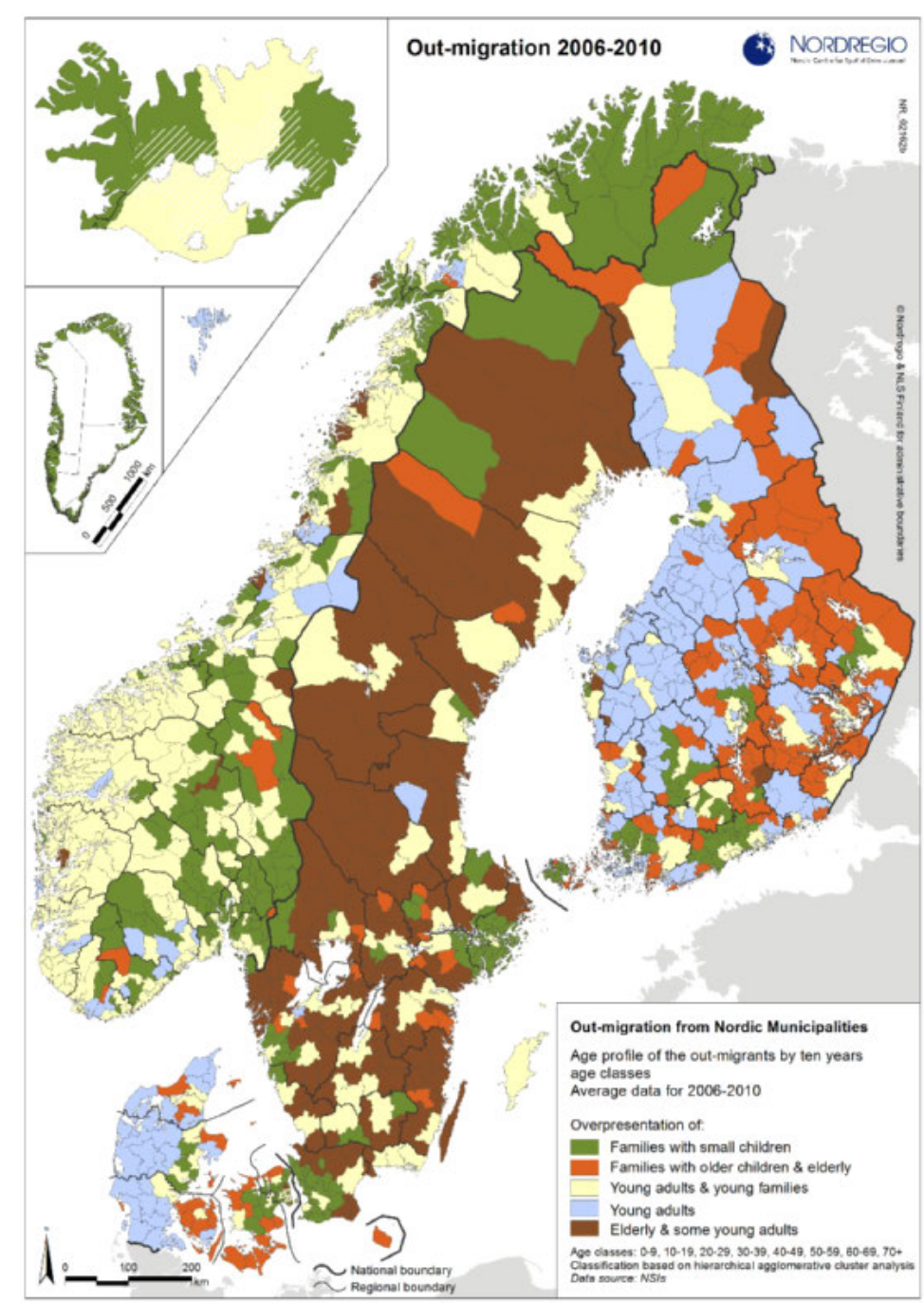

Kilde: NordRegio 2013.

Design: Johanna Roto 
Figur 4: Kortet viser tilflytning (in-migration) i Norden i perioden 2006-2010

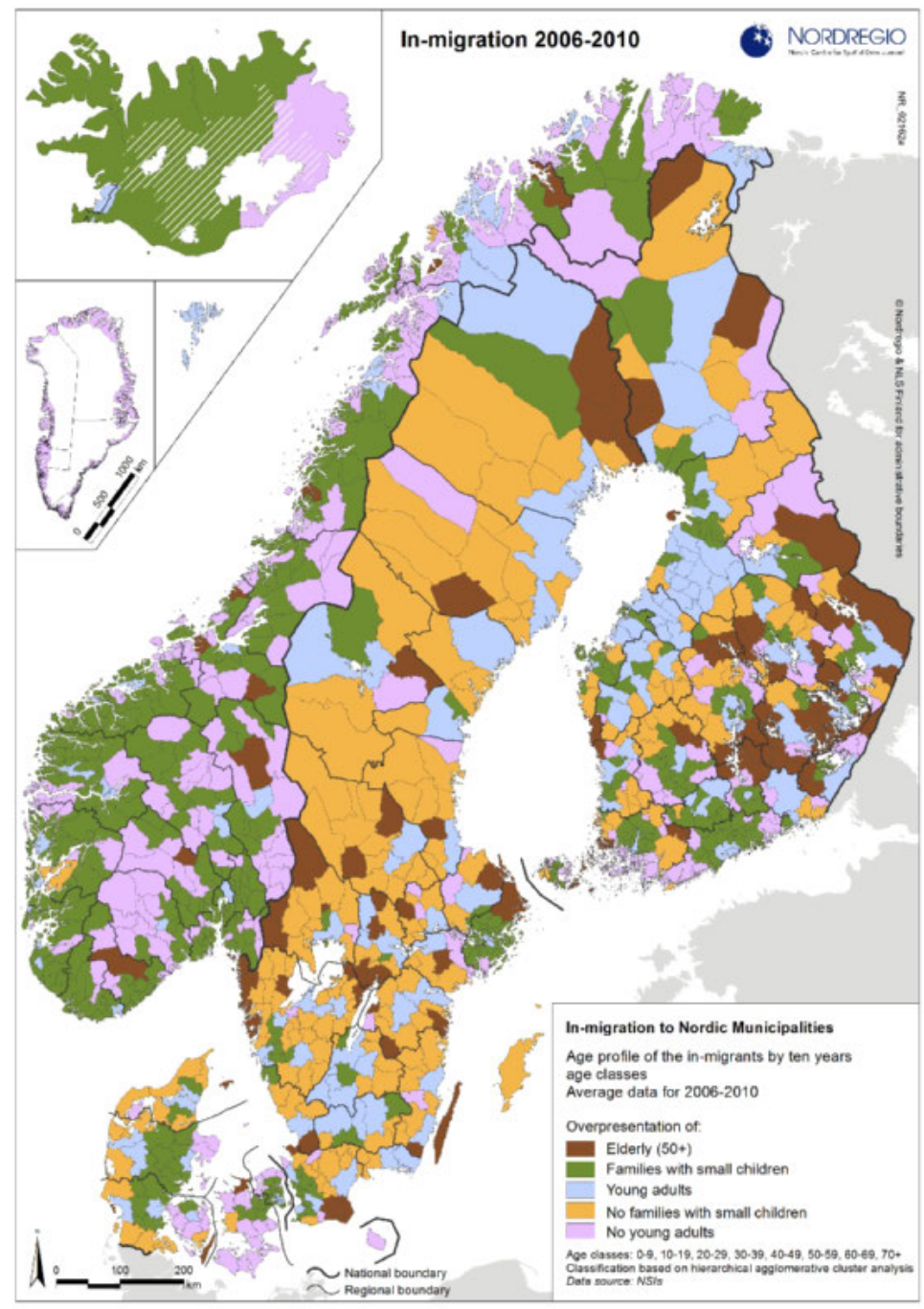

Kilde: NordRegio 2013.

Design: Johanna Roto. 
Kort 5 viser, at migrationsmønstrene blandt mænd og kvinder er ens, men at intensiteten af kvinder, som flytter fra yderområderne er højere, og at dette er en tendens, som går igen i alle de nordiske lande. I begge kort markerer de røde farver en affolkningstendens, mens de blå farver markerer befolkningstilvækst, og de gullige områder har mere eller mindre stabile indbyggertal. Som nævnt er de overordnede samlede tendenser ens for både mænd og kvinder, hvilket kan ses af farverne på kortene.

Figur 5: Kortet viser netto-migrationen for mænd i perioden 2009-2011

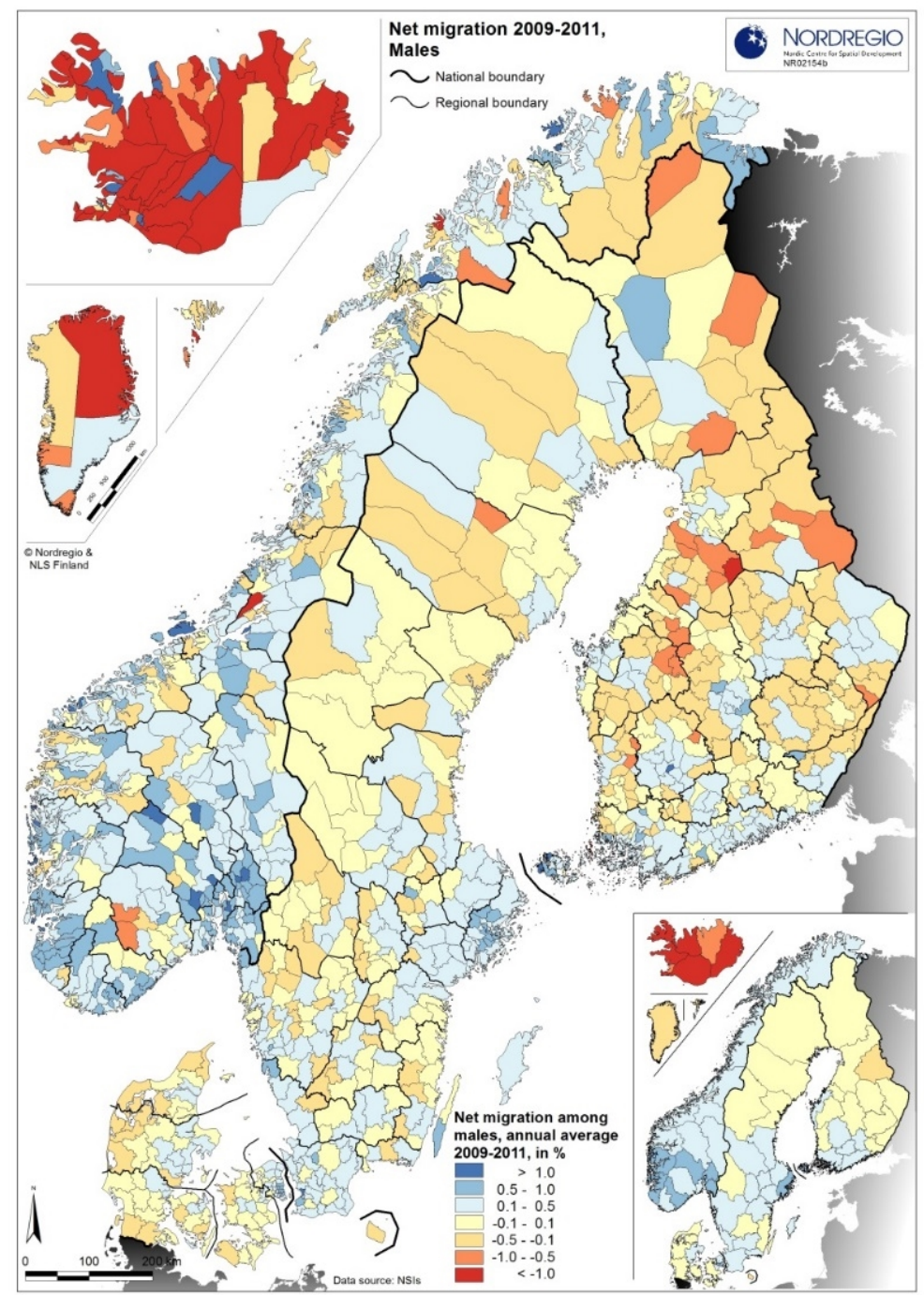

Kilde: NordRegio 2013.

Design: Johanna Roto. 
Kort 6 dominerer de helt mørkerøde (dvs. affolkning) og de helt mørkeblå (dvs. befolkningstilvækst) områder i langt højere grad - med andre ord er det samlede billede af de nordiske kvinders migrationsmønstre langt mere ekstremt end det mønster der ses blandt mændene i kort 5. Til eksempel ses den største netto-migration blandt kvinder i Danmark til hhv. hovedstadsområdet og Aarhus (den anden største by i Danmark). Det samlede resultat på tværs af Norden bliver en overvægt af kvinder i byerne og en overvægt af mænd i yderområderne.

Figur 6: Kortet viser netto-migrationen for kvinder i perioden 2009-2010

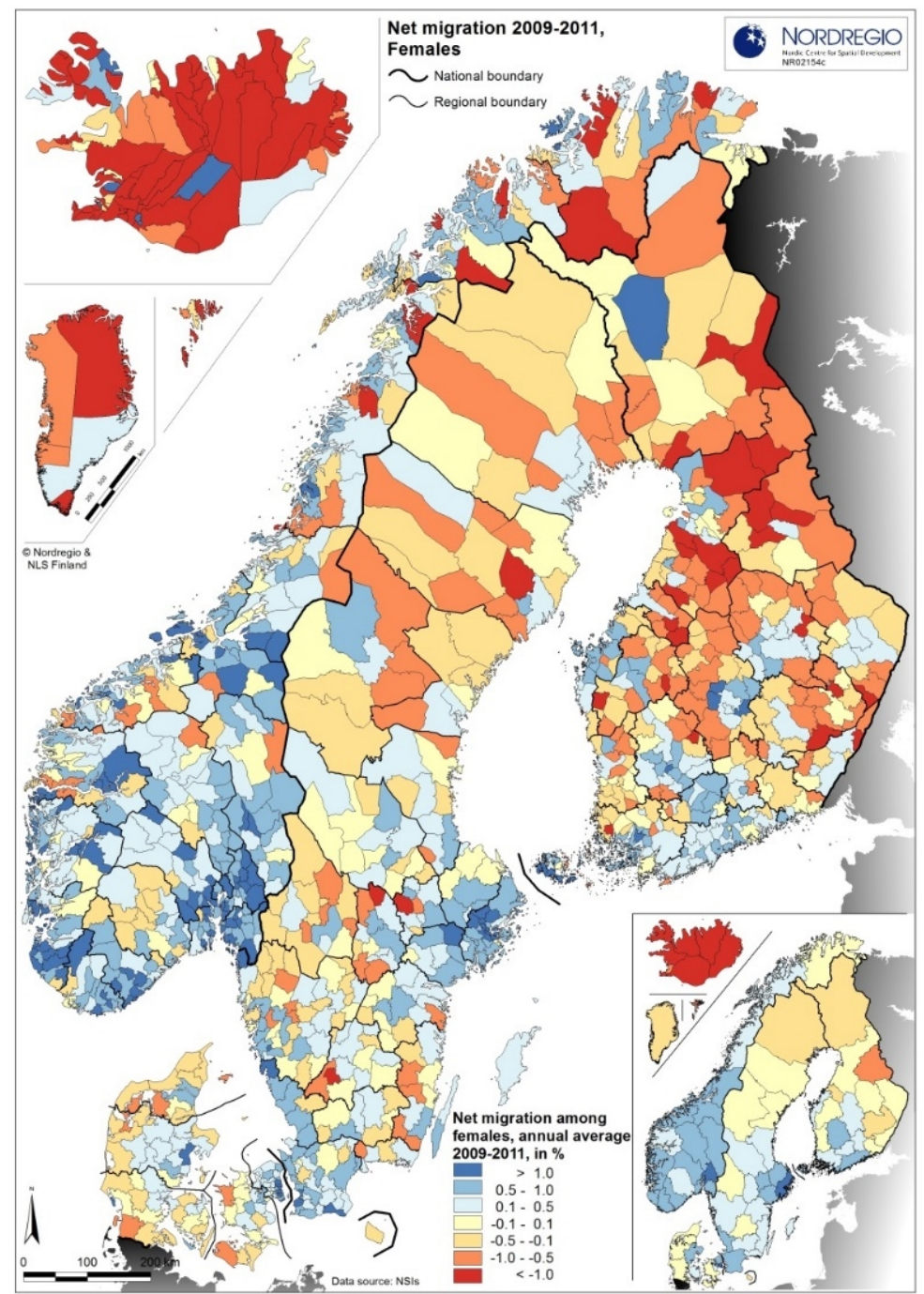

Kilde: NordRegio 2013. Johanna Roto.

Design: Johanna Roto. 
Som det fremgår af de forskellige oversigtskort fra NordRegio, er tendenserne ensartede på tværs af Norden, men særligt udtalt i Vestnorden (Grønland, Færøerne og Island) (se bl.a. Rafnsdóttir 2010). I Grønland er der lavet særligt detaljerede undersøgelser ikke blot i relation til faktiske flyttemønstre, men også bevæggrunde for flytning (se bl.a. Rasmussen 2010). Den grønlandske mobilitetsundersøgelse bekræftede, at der er udtalte kønsforskelle i de angivne årsager til at ville flytte, hvor kvinder angav, at de ønskede at flytte for at få adgang til uddannelse, for at få adgang til flere kultur- og fritidstilbud og for at komme væk fra social kontrol i de mindre lokalsamfund og sikre øgede muligheder for deres børn. Undersøgelsen viste, at mænd i Grønland derimod primært flyttede pga. deres muligheder på arbejdsmarkedet, $\mathrm{fx}$ hvis de oplever, at der er bedre og flere erhvervsmuligheder for dem eller deres partner andre steder. Fælles for besvarelserne fra begge køn i mobilitetsundersøgelsen var ønsket om at være bosat et sted, hvor der er bedre løn, øgede muligheder for offentlig transport og et udvalg af andre offentlige tilbud i forhold til fx sundhed og uddannelse (Rasmussen 2010). 



\section{Hvorfor er det vigtigt at medtænke køn og ligestilling?}

Kortlægningen af forskning og faglitteratur på området dokumenterede, at det er vigtigt at medtænke køn, hvis man vil forstå de udviklingstendenser, som kendetegner Nordens yderområder. Dette understreges også netop af de tal og fakta, som præsenteredes via de forskellige landekort over Norden.

Det er på sin vis ikke nogen ny problemstilling, at kvinderne i de tyndere befolkede områder i Norden flytter ind mod byerne; rent faktisk har forskning i over 100 år peget på denne problemstilling. ${ }^{2}$ De globale udviklingstendenser i nyere tid har imidlertid bidraget til, at de negative tendenser forstærkes, hvilket har givet anledning til begreber som f.eks. kvindeflugt og kvindeunderskud. Samtidig er der i de senere år, indenfor forskningen og i samfundsdebatten, kommet et stigende fokus på de tilbageblevne mænd. Her er det bl.a. blevet fremført, at omstruktureringerne på arbejdsmarkederne i yderområderne (og en markant nedgang i antallet af de såkaldte "mandearbejdspladser") har sat de mere traditionelle former for maskulinitet under pres (Faber, Pristed Nielsen \& Bennike 2015) (se også bl.a. Baagøe Nielsen 2011 samt Gaini 2006).

De ensartede udfordringer, som ydeområderne står overfor, er et resultat af strukturelle, økonomiske og sociokulturelle ændringer. Udfordringerne drejer sig bl.a. om "ændrede lokale erhvervstraditioner og ændrede uddannelsesmønstre i yderområderne, udfordringer vedr. transport, social infrastruktur, lokale tilknytningsmønstre eller mangel på samme, arbejdsmarkedernes kønsopdeling og kønsopdelte uddannelsesvalg, ændring af rekrutteringsmønstre indenfor forskellige sektorer på arbejdsmarkedet, osv. Det er alle udfordringer, som ikke bør/kan analyseres og ej heller løses uden at medtænke kønsperspektivet" (Faber, Pristed Nielsen \& Bennike 2015: 10).

Udviklingen i yderområderne skal nemlig ses og forstås i sammenhæng med den forståelse af steder som "kønnede", som 
forskningen på området peger på. Her er pointen, at "de steder, mænd og kvinder bor, og de sfærer, som de færdes i ( $\mathrm{fx}$ i familien, på uddannelsesinstitutionerne, på arbejdspladsen, osv.), alle er forankret i specifikke geografiske lokaliteter, der er indlejret med forskellige betydninger og forestillinger om, hvad der regnes som socialt acceptabelt. I forlængelse heraf kan man tale om, at de geografiske lokaliteter er med til at definere hvilke mulighedsrum, der eksisterer og herunder hvilke grader af frihed den enkelte mand eller kvinde oplever at have" (Faber, Pristed Nielsen \& Bennike 2015: 7) (se også bl.a. Dahlström 1996; Stenbacka 2011; Rafnsdóttir 2010).

Som det vil fremgå af rapporten her, understreges vigtigheden af at der i arbejdet med at adressere udfordringerne i Nordens yderområder fokuseres på at integrere køns- og ligestillingsperspektiver på alle niveauer - nationalt, regionalt, kommunalt og lokalt. Dette er allerede i nogen grad en del af det arbejde, der udføres i de Nordiske lande via fokus på gender mainstreaming (eller "ligestillingsvurdering", som er den danske betegnelse). Imidlertid fremhæver Rönnblom (2005) i sin analyse af gender mainstreamingindsatsen i Sverige og Norge, at køn og ligestilling ikke altid tænkes som et integreret element $\mathrm{i}$ den regionale/kommunale udviklingsindsats. Rönnblom finder, at ligestilling i denne indsats næsten udelukkende betragtes som noget der vedrører kvinder og ikke både kvinder og mænd, hvilket bevirker, at en række kønsproblematikker ofte bliver analyseret og adresseret for snævert for eksempel i forbindelse med uddannelsestiltag, arbejdsmarkedsinitiativer, trafikplanlægning, kulturtilbud, osv. 


\section{Ligheder og forskelle mellem de nordiske lande}

Som det fremgår af forrige afsnit om tal og fakta, er der en række relevante lighedstræk på tværs af Norden, der gør det oplagt at have fælles erfaringsudveksling og komparative diskussioner. De udfordringer som Norden står overfor i forhold til yderområderne og i relation til køn, uddannelse og befolkningsstrømme rummer mange dimensioner - både på individ-, gruppe- og samfundsniveau, og i samspillet niveauerne imellem. De relevante lighedstræk på tværs af disse forskellige nordiske lokaliteter kommer således til udtryk i uddannelsessystemet, på arbejdsmarkedet og generelt $i$ lokalsamfundene i de nordiske yderområder.

De nordiske lande er ikke bare bundet sammen af historien, men har også i vid udstrækning fælles politiske, kulturelle og værdimæssige rødder, hvilket blandt andet afspejles i opbygningen af velfærdssamfundet og i typer af velfærdsydelser. De nordiske lande er også kendt for historisk at have en høj grad af ligestilling mellem kønnene og for, sammenlignet med mange andre europæiske lande at have et stort fokus på lige muligheder for mænd og kvinder/drenge og piger (se bl.a. Siim og Stoltz 2015).

Når man betragter de nordiske lande samlet, er der imidlertid også en række kontrasterende forskelligheder, for eksempel hvad angår geografiske distancer, befolkningstæthed, fordelingen af naturressourcer, hastigheden hvormed uddannelses- og arbejdsmarkederne ændrer sig, forskelle i karakteristikken af de lokale arbejdsmarkeder, og hvilke sektorer der dominerer, organisering af den sociale infrastruktur samt typer af lokale erhvervsliv, foreningsliv og beskæftigelse. I lyset af dette er der selvsagt variationer i erfaringer og praksis samt i de politiske tiltag på tværs af Norden (Faber, Pristed Nielsen \& Bennike 2015) (se også bl.a. Haagensen 2014).

For Danmark, Norge, Sverige og Finland gælder det, at diskussionen om køn, uddannelse og befolkningsstrømme som udgangspunkt er bundet op på særlige problemstillinger knyttet til bestemte, og oftest de tyndest befolkede, yderområder. Her er fokus overvejende på befolkningsstrømme og unges flytning internt $\mathrm{i}$ landene og/eller pendling for at tage en uddannelse (se bl.a. Bloksgaard, Faber og Hansen 2013). I 
visse yderområder har de danske, svenske og norske unge slet ikke adgang til en ungdomsuddannelse, eller kun adgang til et begrænset udvalg af ungdomsuddannelser, hvilket i praksis kan betyde, at de er tvunget til at flytte hjemmefra i en ganske tidlig alder (se bl.a. Paulgaard 2012 og 2015 samt Bjarnason og Thorlindsson 2006). Der er dog ingen tvivl om, at de geografiske afstande er langt mere markante i Norge og Sverige sammenlignet med $\mathrm{fx}$ Danmark. Det er sandsynligvis også forklaringen på, at der i disse lande er en stærkere forskningstradition, når det kommer til at belyse problematikkerne omkring køn og befolkningsstrømme i relation til uddannelsesvalg. For Island, Grønland, Færøerne samt Åland derimod handler problemstillingerne i mindre grad om regionale/lokale variationer internt i landene, men dog stadig med et blik for forskelle mellem land og by, center og periferi. I disse områder gør det sig gældende, at problematikkerne omkring befolkningsstrømme i relation til uddannelsesvalg ofte fordrer national fraflytning, med affolkning og dalende børnetal til følge, idet mange aldrig vender tilbage (Faber, Pristed Nielsen \& Bennike 2015) (se bl.a. også Hovgaard, Eythórsson og Fellman 2004, samt Rafnsdóttir 2010). 


\section{Eksisterende forskning og faglitteratur - et sammendrag}

Nedenfor opsummeres en række af de gennemgående temaer og tendenser, som blev identificeret i kortlægningen af forskning og faglitteratur relateret til $\mathrm{k} ø \mathrm{n}$, udvikling og befolkningsstrømme. ${ }^{3}$ Kortlægningen afdækkede at:

\subsection{De unge i yderområderne føler et stort pres for at forlade deres lokalsamfund}

Litteraturen viser, at unge - og især kvinderne - i Nordens yderområder træffer deres valg på baggrund af meget forskellige vilkår, fordi de ofte enten er decideret tvunget til og/eller føler et stort pres for at forlade deres lokalsamfund. Den afdækkede litteratur understreger samtidig, at unge af begge køn forlader deres hjemstavn i yderområderne, ikke kun fordi de ønsker at se og opleve verden eller fordi dét at flytte er et naturligt led i at blive voksen, men også fordi det føles umuligt for dem at blive enten pga. manglende uddannelses- og jobmuligheder, eller fordi de finder lokalsamfundene i yderområderne begrænsende eller klaustrofobiske.

\subsection{Det er ofte uddannelses- eller arbejdsrelateret, når unge (især kvinderne) flytter}

Kortlægningen viser, at de unge i Nordens yderområder har forskellige forhåbninger om, hvorvidt der på længere sigt er en plads til dem det sted, de bor. 0 g netop her synes køn at spille en væsentlig rolle, idet der på tværs af den nordiske litteratur peges på, at de ændrede vilkår i yderområderne gør, at de unge kvinder i højere grad oplever, at der er

${ }^{3}$ Opsummeringen i dette afsnit er et komprimeret uddrag fra kortlægningsrapporten "Sted, (U)lighed og Køn En kortlægning af udfordringer og best practices i relation til køn, uddannelse og befolkningsstrømme i Nordens yderområder" (2015), udarbejdet af Faber, Pristed Nielsen \& Bennike. 
begrænsninger knyttet til deres køn, fx når de vurderer deres fremtidige muligheder på de lokale arbejdsmarkeder. Dette synes, i højere grad end det gør sig gældende for de unge mænd, at kollidere med de unge kvinders ønsker om, hvordan de gerne vil leve på sigt, og hvad der faktisk er muligt de steder, de bor. Således fremgår det af kortlægningen, at de unge kvinder i yderområderne satser på videregående uddannelse i højere grad end de unge mænd. Litteraturen på området peger endvidere på, at kvindernes ønske om at flytte fra yderområderne i nogen grad kan knyttes sammen med et ønske fra kvindernes side om at få adgang til flere og lige muligheder - indenfor uddannelse, arbejdsliv og i hverdagslivet samt en større grad af frihed fra kønstraditionelle forventninger og normer (uddybes senere).

\subsection{Stedet, hvor de unge bor, danner præmisserne for deres muligheder og valg i forhold til uddannelse}

Selvom vi i Norden på nationalt plan har et politisk ideal om ligestilling, viser kortlægningen, at der er kontekstspecifikke variationer. På den måde kan man tale om, at den norm om lige muligheder for alle som kommunikeres i de nordiske uddannelsessystemer ikke altid korresponderer med den faktiske situation i Nordens yderområder. Kortlægningen peger således på, at det på tværs af Norden er vigtigt at stille spørgsmålet om, hvorvidt mænd og kvinder nu også reelt har lige adgang til at opnå den uddannelse/efteruddannelse, de måtte ønske sig. Det sted, de unge bor, sætter sine begrænsninger for, hvad der er realistisk og tilgængeligt, og således er stedet med til at forme den mulighedshorisont, som de unge forholder sig til. Dette ses $\mathrm{fx}$ helt konkret ved, at nogen drenge/unge mænd i yderområderne fravælger at tage en ungdomsuddannelse (fx en erhvervsuddannelse), fordi der mange steder ikke findes en sådan uddannelsesinstitution i området.

\subsection{Stedet, hvor de unge bor, danner tillige præmisserne for engagement og lyst til læring}

At de steder, de unge bor, er med til at danne præmisserne gælder ikke bare for de unges muligheder og valg, hvad angår uddannelse og arbejdsliv, men i nogen grad også for deres engagement og lyst til læring. I nogle yderområder tilsiger det lokale arbejdsmarked og erhvervsliv mindre uddannelse, hvormed det at fravælge uddannelse fremstår som 
et fornuftigt og rationelt valg. Kortlægningen afdækker også, at uddannelsesinstitutionernes kultur af nogle elever opleves som "fremmed", fordi deres identiteter er forankret i et lokalsamfund, hvor fokus er på en anden type af værdier og former for kulturel/social kapital. Forskningen på området peger, at især de unge mænd, potentielt oplever en kulturel kollision; en kollision mellem på den ene side de værdier og den opfattelse af hvad der kendetegner "det gode liv" de unge mænd har, og på den anden side den uddannelses- og karriereorienterede fortælling (diskurs), som fremføres bl.a. i medierne og af politikere på den nationale scene, og som cementerer, dels at man som ung må være omstillingsparat og mobil (villig til at flytte), dels at boglig uddannelse er vejen frem.

\subsection{Den geografiske mobilitet er ofte koblet til social mobilitet}

Som det fremgår af forskningen på området, er uddannelse af central betydning for unges livsforløb både $\mathrm{i}$ form af tilpasninger til det omgivende arbejdsmarked og udformning af levevis, livsstil og identitet. For unge fra de nordiske yderområder og fra de mindre bysamfund i disse områder indebærer det at vælge en videregående uddannelse ofte også flytning fra hjemstedet. Samtidig er den geografiske mobilitet i mange tilfælde tillige koblet til social mobilitet, idet en del af de unge fra yderområderne kommer fra hjem og/eller lokale miljøer, hvor det at tage videregående uddannelse ikke har været sædvane. Der er ikke et udpræget kønsperspektiv knyttet til denne problemstilling, men svensk forskning peger på, at en svag tilknytning til arbejdsmarkedet og et lavt uddannelsesniveau ikke nødvendigvis vurderes som et problem for de unge mænd i yderområderne, som har en arbejderklassebaggrund. Her er det blevet fremhævet, at disse unge mænd selv ofte vurderer, at de er bedre stillede ved netop at blive fremfor at flytte; fordi den kultur de kan lide, og de privileger som de har som mænd i lokalområdet, ikke har samme gyldighed udenfor yderområderne. 


\subsection{Både det kønsopdelte uddannelsesvalg og det kønsopdelte arbejdsmarked er udtalt i Nordens yderområder}

Det lokale (og regionale) arbejdsmarked i yderområderne danner en ramme, som de unge vurderer deres muligheder op i mod. Litteraturen på området peger på, at det ikke kun er uddannelsesmulighederne, men også mulighederne på arbejdsmarkedet, der har betydning for ungdommens, og især de unge kvinders, ønske om at ville flytte væk eller på sigt vende hjem igen. Forskningen peger på, at de unge mænd ofte er tættere forbundet med de typer af erhverv og livsmønstre, som kendetegner yderområderne, selvom der også her kan arbejdes med behovet for omskoling af mænd til de såkaldte "kvindefag". Med henblik på at kunne sikre at flere af de unge kvinder vælger at blive eller vælger at flytte tilbage til deres lokalområder efter endt uddannelse, synes det helt konkret at være nødvendigt at skabe lokale arbejdsmuligheder i yderområderne, som forudsætter videregående uddannelse.

\subsection{De unge kvinder i yderområderne oplever ikke bare at have færre muligheder på de lokale arbejdsmarkeder, men også i det lokale foreningsliv, ved fritidsaktiviteter og i kulturelle udbud}

Når de unge kvinder i periferien ofte oplever at have færre muligheder end de unge mænd, handler det ikke kun om, at jobmulighederne i yderområderne (ofte indenfor den primære sektor) ofte ikke føles tilgængelige for dem i samme omfang. Der er også andre aspekter, der fremhæves i forskningen på området; bl.a. at typen og graden af foreningsliv, fritidsaktiviteter og kulturelle udbud spiller en vigtig rolle i de unges valg om enten at blive i yderområderne eller at flytte - og her peger litteraturen på, at de aktiviteter, som de unge mænd deltager i ( $\mathrm{fx}$ jagt, fiskeri og friluftsliv eller $\mathrm{fx}$ via de lokale erhvervsfaglige fællesskaber), synes at knytte dem mere til stedet, end de aktiviteter, som de unge kvinder deltager $\mathrm{i}$. 


\subsection{Den stærke kønssegregering af de nordiske arbejdsmarkeder forstærker de negative udviklingstendenser i yderområderne}

Et fællestræk på tværs af de nordiske landes arbejdsmarkeder er en stærk tendens til kønssegregering - mere udtalt i visse lande fremfor andre, men ikke desto mindre er der en generel tendens til, at kvinderne arbejder i den offentlige sektor og mændene i den private - og at særligt den primære sektor (landbrug, skovbrug, råstofudvinding) i høj grad er domineret af mænd. Denne kønssegregering af arbejdsmarkedet har i flere nordiske yderområder været medvirkende årsag til, at særligt mændene har været hårdt ramt af den økonomiske krise, idet antallet af traditionelle mandejobs er faldet betydeligt i flere områder.

\subsection{Yderområderne rummer potentielt iboende patriarkalske strukturer, der skubber de unge kvinder væk}

I en del af litteraturen på områder fremhæves det, at yderområderne har en tendens til at skubbe kvinderne væk bl.a. pga. iboende patriarkalske strukturer. Således bliver det bl.a. konkluderet, at flere af de unge kvinder betragter dét at flytte bort fra de små lokalsamfund i yderområderne og tage en uddannelse som afgørende for at kunne udforme egen identitet og skabe en livsstil frikoblet fra lokale kulturelle og strukturelle begrænsninger; herunder kønnede forventninger til kvinders rolle/ansvar, parforhold og moderskab - kønnede forventninger som disse unge kvinder oplever vil begrænse deres handlingsrum.

\subsection{Nogle mænd i yderområderne bliver særligt ramt af de lokale arbejdsmarkeders omstrukturering og de ændrede levevilkår}

Af litteraturen på området fremgår det, at mændene i yderområderne synes at blive særligt ramt af den omstrukturering af arbejdsmarkedet 
og de ændrede livsvilkår, som kendetegner yderområderne i alle de nordiske lande. Det er ydermere blevet fremhævet, at de senere års finanskrise har skubbet denne udvikling yderligere på vej, hvorfor man i et ligestillingsperspektiv ikke taler om the recession, men om the mancession (Weyhe 2011). Dette skal sammenholdes med, at der i dag er stor fokus på mobilitet og fleksibilitet, hvilket ifølge forskningslitteraturen er med til at skabe en særlig negativ fortælling om de tilbageblevne mænd i yderområderne. Litteraturen peger på, at der er mænd i yderområderne, som oplever ambivalens, og nogle udviser også tegn på det, der inden for forskningslitteraturen, er blevet omtalt som melankolsk maskulinitet (McDowell 2003). Dette skal ses i sammenhæng med, at mange af de unge mænd i yderområderne er vokset op med en traditionel kønsforståelse, hvor maskulinitet og hårdt fysisk arbejde er tæt forbundet. Med omstruktureringen på de lokale arbejdsmarkeder, og stigende arbejdsløshed indenfor de traditionelle mandefag, bliver denne forståelse udfordret.

\subsection{I yderområderne bor også mænd, som har truffet bevidste valg - som bliver boende, fordi de trives netop her}

I diskussionen om det kvindeunderskud, der præger mange af Nordens yderområder, er det også relevant at understrege, at det ikke kun handler om at lokke nye tilflyttere (især kvinder) til yderområderne, men at det også kan handle om at værne om dem (især mænd), som bliver boende og i forlængelse herfra at løfte mere positive billeder frem. Tendensen til at de unge mænd har en større grad af stedtilknytning end de unge kvinder handler nemlig ikke kun om en særlig type livsmønster, om faglige fællesskaber i relation til lokale erhvervstraditioner eller om at fritidstilbuddene i yderområderne harmonerer godt med traditionelle mandeinteresser - det handler ifølge litteraturen også om, at de unge mænd bliver boende, fordi de foretrækker livet på landet, og fordi de oplever, at der er nogle værdier, som de kun/bedst kan praktisere her. At de tilbageblevne mænd i yderområderne kan hænde at have truffet bevidste og velovervejede valg om bopæl, uddannelse og erhverv, indgår i mindre grad som et element i den tværnordiske debat. 
Vidste du at... - om kvinder/femininitet i Nordens yderområder

- At forskning længe har peget på, at kvinder i de tyndt befolkede yderområder i Norden har en større tendens end mænd til at flytte ind mod byerne.

- At mange unge kvinder i yderområderne oplever, at stederne udbyder flere muligheder til de unge mænd, når det kommer til uddannelse, erhverv og fritid.

- At mange kvinder flytter mod byerne for at studere, og efterfølgende oplever det som svært at vende tilbage til lokalområderne, idet jobmulighederne i yderområderne ikke matcher deres tilegnede kvalifikationer.

- At lokale kønsnormer kan være medvirkende til, at de unge kvinder ønsker at flytte til byerne, som de opfatter som mere moderne og ligestillede.

- At kvinder der sætter pris på traditionelle kønsroller bedre kan se en fremtid for sig i de små lokalsamfund.

\section{Vidste du at... - om mænd/maskulinitet i Nordens yderområder}

- At forskning har påvist, at der blandt visse unge mænd i yderområderne er en tendens til ikke at prioritere skolen, fordi boglig viden ikke vurderes at være omsætteligt på det lokale arbejdsmarked.

- At der er en tendens til at unge mænd i yderområderne i højere grad end de unge kvinder er glade for at bo, hvor de bor, bl.a. fordi de aktiviteter de er med i (fx jagt, fiskeri og friluftsliv) knytter dem til stedet.

- At mange unge mænd ser en positiv værdi i valget om at blive boende i deres lokalområde.

- At det ofte opfattes som naturligt for drengene i Nordens yderområder at overtage deres fædres erhvervstraditioner.

- At den fremherskende maskuline kultur i nogle af Nordens yderområder, som er baseret på bl.a. jagt, udendørsaktiviteter, og håndværksmæssige evner kan vanskeliggøre, at mænd, som fx har taget en akademisk uddannelse bliver/føler sig accepteret i lokalsamfundet.

Kilde: Faber, Pristed Nielsen \& Bennike 2015. 



\section{Indspil til politiske beslutningstagere og andre myndigheder samt udvalgte praksiseksempler}

I forrige afsnit har vi præsenteret et udsnit af, hvad den eksisterende forskning og faglitteratur på området har peget på. Vi skal nu gå et skridt videre og med afsæt i den tværnordiske dialog og erfaringsudveksling præsentere, hvordan denne viden potentielt kan omsættes til handling i praksis, fx i forhold til at udforme nationale uddannelsespolitikker eller implementere tiltag i de enkelte nordiske lande. Her er der, som det vil fremgå, blevet peget på forskellige tematikker og indsatsområder, hvor det ikke bare er oplagt men også muligt at arbejde med national/regional/kommunal/lokal udvikling i et kønsperspektiv og derned potentielt påvirke unges mulighedsrum og erfaringer og dermed også adressere de udfordringer, som yderområderne står overfor. Gennemgangen tager konkret afsæt i en identificering af fem tematikker, som indeholder særlige kønsproblematikker i relation til uddannelse, arbejde, fritidsliv, befolkningsstrømme og identitet i Nordens yderområder. For hver tematik gives der, med udgangspunkt i de erfaringer og faglige indspil, som er kommet frem undervejs i den fælles tværnordiske dialog og erfaringsudveksling, bud på indsatsområder samt praksiseksempler der er rettet mod at imødegå de eksisterende udfordringer på tværs af Nordens yderområder.

De fem tematikker er:

1. Begrænset adgang til uddannelse i yderområderne.

2. Omstrukturering af yderområdernes arbejdsmarkeder.

3. Kvinder finder livet i yderområderne mindre attraktivt.

4. Arbejdsudbuddet er for snævert i yderområderne.

5. Yderområdernes stigma påvirker de unge af begge køn. 


\subsection{Tema: Begrænset adgang til uddannelse i yderområderne}

Problemstilling: Øgede krav og forventninger til formel uddannelse samt kønssegregerede uddannelsesvalg.

I visse af Nordens yderområder har de unge jf. tidligere ikke adgang til hverken en ungdomsuddannelse eller videregående uddannelse, eller kun adgang til et begrænset udvalg af uddannelser og/eller studieretninger, hvilket i praksis kan betyde, at de er tvunget til at flytte hjemmefra i en ganske tidlig alder. Tidligere studier viser, at det især er de unge kvinder i yderområderne, der flytter tidligt hjemmefra (Faber, Pristed Nielsen \& Bennike 2015). Dog skal det her siges, at der er forskellige traditioner på tværs af de Nordiske lande; fx er der i både Grønland, Island og Færøerne tradition for, at de unge af begge køn rejser væk (primært til Danmark) for at tage en uddannelse. Men hvor en stor del af grønlandske og færøske unge ikke vender hjem igen, er der i Island større tradition for, at de unge vender tilbage og bruger deres erhvervede uddannelse her.

Den manglende og/eller begrænsede adgang til uddannelse i Nordens yderområder er problematisk, da der samtidig politisk, socialt og blandt de unge selv er øgende krav og forventninger om en formel uddannelse. Kravene til øget uddannelse findes både på det lokale, regionale og nationale arbejdsmarked, og er samtidig en del af en generel (og global) tendens til øgede krav og forventninger til unges uddannelsesniveau. Dette hænger sammen med, at selv de traditionelle jobs indenfor fx landbrug og fiskeri i dag kræver andre kompetencer end tidligere bl.a. indsigt i fx økonomi, ledelse, sikkerhedskrav mm.

De unge i yderområderne spejler sig i andre unge, bl.a. via internet og sociale medier - og den globale/nationale fortælling er, at uddannelse er nødvendig. Det kan være vanskeligt for de unge, som i en tidlig alder (ofte omkring 16 år) er nødt til at rejse hjemmefra for at tage en ungdomsuddannelse, hvilket kan resultere i, at de enten helt dropper at tage en videregående uddannelse eller får startet op for siden at droppe ud af studiet - begge dele med store omkostninger for de unge selv, for lokalsamfundene og for samfundet som et hele.

Mulige indsatsområder: Decentralisering af uddannelsesudbud, fjernundervisning, fokus på transportmuligheder, særlig støtte til unge der må flytte langt.

En væsentlig pointe, som går igen i samtlige af de nordiske lande i forhold til uddannelse og forsøget på at imødekomme utilsigtede kønnede konsekvenser, er vigtigheden af at medtænke uddannelsestilbuddenes 
geografiske placering i planlægningen. Til eksempel pendler drenge i Danmark længere end piger, fordi erhvervsuddannelserne (typisk med en overvægt af mandlige studerende) geografisk ligger langt mere spredt end de almene gymnasier, og desuden pendler drengene også ofte til og fra en læreplads. Dette kan vanskeliggøre deres muligheder for at have et aktivt fritidsliv og samtidig også afholde nogle drenge fra at tage en uddannelse. Når man diskuterer muligheden for at samle uddannelsesinstitutioner i færre men større enheder, er det derfor vigtigt at drage disse overvejelser med ind i diskussionen. Dette understreges også af, at hidtidig forskning peger på, at flere drenge end piger har en tendens til at falde fra deres uddannelse, hvis de er nødsaget til at bo på skolehjem eller pendle langt for at få en uddannelse. På den måde kan man tale om, at centraliserede uddannelsesinstitutioner dermed mere eller mindre indirekte dis-favoriserer drengene.

Forskningen viser jf. tidligere, at unge mænd i hele Norden i højere grad end pigerne er knyttet til lokalområderne $\mathrm{fx}$ igennem fritidsaktiviteter, og at de unge mænd også i højere grad finder fodfæste i de traditionelle erhverv som fx fiskeri og skovbrug, hvilket også gør, at de er knyttet til lokalområdet socialt og erhvervsmæssigt i en større grad end pigerne og dermed har større incitament for at blive boende.

Derudover kan placeringen af en uddannelsesinstitution virke som en motor for forskellige former for udvikling i yderområderne - fx kan der peges på universitetet i Akureyri (Island), der er vokset fra oprindeligt 4 medarbejdere og 50 studerende i 1987 til 169 medarbejdere og 1.703 studerende i 2014. Samtidig ses det, at den nordøstlige region hvor dette universitet er placeret, er den eneste region i Island, hvortil der sker en nettoindvandring af islandske kvinder. En repræsentant fra KUN (Senter for kunnskap og likestilling i Nordfold) fremførte i den fælles tværnordiske dialog, at det er væsentligt at have for øje, at en aktiv lokal indsats og placering af uddannelsesinstitutioner kan skabe basis for en positiv lokal udvikling.

Fjernundervisning i yderområderne er et område, der af nogle forskere vurderes at kunne have en positiv virkning i forhold til at modvirke fraflytning blandt de unge, da de unge derved vil være i stand til at tage dele af eller hele ungdomsuddannelser eller videregående uddannelser via fjernundervisning, og dermed opnå et højt uddannelsesniveau samtidig med, at de beholder tilknytningen til lokalområdet. Derudover kan fjernundervisning biddrage til at efteruddanne lokalbefolkningen for at sikre, at der lokalt eksisterer kompetencer i forhold til at varetage nye jobs indenfor andre sektorer, $\mathrm{fx}$ sundhedssektoren der generelt er i vækst i hele Norden. Der findes 
ganske mange gode erfaringer med fjernundervisning af forskellig art på tværs af Norden. I 1970'erne var der fokus på at udflytte uddannelsesinstitutioner i de nordiske lande, fx blev der i både Norge, Danmark og Finland etableret decentrale universiteter for at afhjælpe fraflytningen og styrke uddannelsesniveauet udenfor hovedstadsområderne. Det er fortsat tydeligt, at det især er de tekniske uddannelser, som tiltrækker mændene, og at kvinderne nu generelt er overrepræsenterede på de videregående uddannelser.

Urbanisering er en tendens, der er velkendt i alle de nordiske lande. De unges tilknytning til lokalområdet er derfor en væsentlig faktor i forhold at få de unge til at blive i yderområderne eller komme tilbage efter uddannelse i de større byer. Som en del af den tværnordiske erfaringsudveksling blev det pointeret, at den såkaldte "Laks-effekt" (at de unge flytter til byerne, men søger hjem for at yngle dvs. få børn) ikke længere fungerer, og at det derfor er vigtigt fremadrettet at knytte børnene/de unge til deres lokalområder på anden vis. Samtidig er det vigtigt at støtte børnene/de unge i deres valg om at flytte, men hvis koblingen til lokalområdet er stærk, er der større sandsynlighed for, at de vender tilbage efter endt uddannelse. Det er derfor vigtigt, at lokalområder kontinuerligt signalerer, at de vil de unge, også mens de er væk, og at der er brug for dem i lokalområdet, når de er færdiguddannede.

\subsubsection{Konkrete indspil vedr. manglende eller svær adgang til uddannelse i yderområderne}

- Det er vigtigt at afdække kønsproblematikker i forhold til udbuddet af uddannelser i nordens yderområder, herunder også med et kønsblik på uddannelsesinstitutionernes beliggenhed, på de lokale uddannelsestilbud, transportmuligheder, osv. Dette kunne gøres ved at tage højde for at tilgodese målgrupper af begge køn i de forskellige tilbud.

- Kønsopdelte uddannelsesvalg mv. kræver bevidsthed omkring betydningen af køn. I udformningen af uddannelsestilbud er det således centralt at have fokus på at imødekomme kønsskævheder i yderområderne, såvel som i centrene. Helt konkret betyder det fx, at uddannelsestilbud i højere grad skal forsøge at appellere til både drenge og piger, og at der bør arbejdes bevidst med at udgå at præsentere kønsstereotype forventninger, normer og idealer for henholdsvis drenge/piger, unge mænd/kvinder. Sidstnævnte bør især medtænkes i den indsats, der foregår på uddannelsesinstitutionerne 
blandt lærere samt studievejledere. Det er især her, der kan arbejdes på at bryde med den stærke kønssegregering i unges uddannelsesvalg.

- Udbydelse af videregående uddannelser via fjernundervisning, så de studerende har mulighed for at blive i deres lokalområde under en stor del af studiet kan være et led $i$ at fastholde de unge $i$ yderområderne og samtidig gøre det muligt for dem at tage en uddannelse. Der er også mulighed for at bruge fjernundervisning på ungdomsuddannelserne.

\subsubsection{Praksiseksempler vedr. manglende eller svær adgang til uddannelse i yderområderne}

- Et eksempel på udbydelse af videregående uddannelser via fjernundervisning er LOSA projektet fra Norge. LOSA står for "Lokal Opplæring i Samarbeid med Arbeidlivet" og projektet tilbyder decentral internetbaseret undervisning til unge i landkommuner. Eleverne får internetbaseret vejledning fra undervisere, via msn, Skype, e-mail, videolink og telefon, men kan også ind imellem mødes i et klasselokale med en større gruppe til mere traditionel klassebaseret undervisning. LOSA tilbydes både indenfor den traditionelle gymnasieuddannelse, samt en række erhvervsuddannelser erfaringerne er, at der ikke generelt brydes med det kønsopdelte uddannelsesvalg, men i det mindste tilbydes der uddannelser der traditionelt tiltrækker både piger og drenge.

- I Sverige har man erfaringer med at videreuddanne unge drenge med et lavt uddannelsesniveau, et såkaldt "collegeår", hvor de unge har mulighed for at indhente/opbygge de kvalifikationer/kompetencer som de mangler og samtidig få arbejdsløshedsunderstøttelse.

- Både fra Nordnorge og fra Sverige findes der eksempler på erfaringer med at involvere det lokale arbejdsmarked, der har en interesse i at de unge bliver i regionen. Dette kan fungere som et virkemiddel, hvis de lokale arbejdsgivere kan bidrage fx med praktikpladser undervejs i et uddannelsesforløb, eller hvis de kan tilbyde deltidsarbejde i kombination med at man fx tager en ungdomsuddannelse på deltid.

- Mht. behovet for særlig støtte for unge, der må flytte langt for at få en uddannelse, blev der i den tværnordiske dialog nævnt, at der i Finland eksisterer et ekstra studiebidrag til studerende, som kommer fra yderområderne, således at de har råd til at rejse hjem på besøg, mens de studerer i byerne. Dette kan ikke bare bidrage til at hjælpe de unge i 
forhold til hjemvé m.m. men også sørge for at de bevarer tilknytningen til deres hjemstavn.

\subsection{Tema: Omstrukturering af yderområdernes arbejdsmarkeder}

Problemstilling: Globaliseringen og finanskrisen har særligt sat traditionelle mandefag under pres.

Globaliseringen og finanskrisen har særligt sat traditionelle mandefag under pres, hvor outsourcing, global konkurrence og effektivisering fx i forarbejdningsindustrien har betydet nedlæggelse af mange "mandearbejdspladser", og traditionelle fag som landbrug og fiskeri rummer i dag ej heller beskæftigelsesmuligheder på samme måde og i samme omfang som tidligere. Det har ført til, at nogle kønsforskere jf. tidligere omtaler den seneste globale finanskrise fra 2008 og frem ikke blot som "the recession", men som "the mancession" (Weyhe 2011). Der er ingen tvivl om, at den globale udvikling skaber en skævvridning i forhold til beskæftigelse blandt mænd og kvinder i yderområderne, da det i særlig grad er kvinderne, som dominerer i de offentlige stillinger, samt indenfor sundhed og helse - og disse jobs kan typisk ikke outsources i samme omfang (omend anden bølge af finanskrisen også har medført besparelser i den offentlige sektor). Derfor har en række initiativer (både på kommunalt, regionalt og nationalt niveau) haft fokus på at få flere mænd til at uddanne sig/lade sig omskole indenfor fx service- og omsorgssektoren. Dette er to sektorer på de nordiske arbejdsmarkeder, som i mindre grad er under pres - bl.a. pga. en øget forsørgerbyrde grundet generelt aldrende befolkninger i hele Norden.

Mulige indsatsområder: Bryd med kønssegregering både inden for uddannelsesområdet og på arbejdsmarkedet. Arbejd på at bløde forestillingerne om henholdsvis "kvindejobs" og "mandejobs" op. Arbejd med omskoling og opkvalificering af mænd i yderområderne.

Det er vigtigt at medtænke køn i arbejdsmarkedsstrategier. Så længe arbejdsmarkederne forbliver stærkt kønssegregerede, er det svært at dæmme op for effekterne for det ene eller det andet $k ø n$ og skabe balance i arbejdsudbuddet i yderområderne. Ét af de mest markante eksempler i Norden på effekten af kønssegregerede arbejdsmarkeder findes i Åland. Her har der været stor fremgang inden for "kvindefag", og således er antallet af beskæftigede i den offentlige sektor vokset med hele $20 \%$ i perioden 2000-2010. Hvorimod der er sket et stort fald i beskæftigelsen i shippingbranchen på $8 \%$ - og netop shippingbranchen er af den største 
betydning for det ålandske arbejdsmarked (ÅSUB 2013). Dette betyder samlet set, at mændene i langt højere grad end kvinderne bliver ramt af de svingende konjunkturer indenfor det private arbejdsmarked.

Som et eksempel handler "mancession" især blandt grønlandske mænd om manglen på jobs indenfor de traditionelle "mandefag" som fx fiskeri (Weyhe 2011). I den tværnordiske dialog blev det fx fremhævet, at arbejdsmarkedet i Grønland er stærkt kønsopdelt, og at der i perioden 2008-2013 er forsvundet 700 jobs indenfor fiskeri og landbrug. Disse jobs forsvinder fra fiskeriet bl.a. pga. effektivisering og centralisering ( $\mathrm{fx}$ på fiskefabrikkerne, men også fordi fangstbådende bliver større og bedre). Samtidig er $59 \%$ af jobbene i den offentlige sektor besat af kvinder. Derudover stiger mængden af jobs i den offentlige sektor, hvor kvinderne har "vundet" 240 jobs i løbet af de seneste år. Endvidere er mange "mandejobs" i Grønland desuden sæsonbestemte (husbyggeri og fiskeri er i stilstand om vinteren), hvilket bevirker, at der i Grønland er i alt ca. 4.900 ledige mænd i vinterperioden, mens der i august-september er 2.000 af dem, som har fået job igen. Dette var én af de pointer, der blev fremhævet i den tværnordiske dialog bl.a. af en repræsentant for Det Grønlandske Ministerium for Erhverv, Arbejdsmarked og Handel.

\subsubsection{Konkrete indspil vedr. tilbagegang i antallet af traditionelle "mandearbejdspladser"}

- Overvejelserne om hvor offentlige arbejdspladser skal placeres og/eller hvilke der skal nedlægges, bør tænkes sammen med overvejelser om de kønnede konsekvenser; herunder overvejelser om hvorvidt det primært vil påvirke mandlige eller kvindelige medarbejdere.

- Jobcentre, fagforeninger og arbejdsgivere kan i fællesskab arbejde på at bryde med den stærke kønssegregering på arbejdsmarkedet - $\mathrm{fx}$ ved at fremhæve rollemodeller/eksempler på hhv. mænd og kvinder der har valgt kønsutraditionelt i deres arbejdsliv.

- En anden problematik omhandler "tilbageskuende vs. fremadskuende maskulinitet" (McDowell 2003). Begrebet sigter på at fange den problematik, at visse mænd i yderområderne forbinder maskulinitet med traditionelle former for erhverv og arbejde, hvilket kan fastholde dem i forestillinger om uddannelses- og erhvervsvalg, der ikke leder til jobsikkerhed. Der blev derfor i den tværnordiske dialog fremsat ideer til at imødegå problematikken omkring tilbageskuende maskulinitetsformer ved at fremhæve rollemodeller, og fx præsentere 
unge drenge for mænd, der har haft succes i arbejdslivet i ikketraditionelle jobs.

- I forlængelse af ovenstående er manglen på mandlige pædagoger i yderområderne et væsentligt område at se nærmere på, da mænd i pædagogfaget har en væsentlig betydning for andre unge mænd i yderområderne, idet de kan agere rollemodeller og give råd og vejledning. Et indsatsområde kunne derfor være at fokusere på mulighederne for efteruddannelse og uddannelse senere i livet for mænd, der ønsker at blive fx pædagog eller sundhedsarbejder.

\subsubsection{Praksiseksempler vedr. tilbagegang i antallet af traditionelle "mandearbejdspladser"}

- Den islandske fagbevægelse peger på muligheden for, at fagbevægelsen aktivt medtager krav om uddannelsesfonde, når der forhandles overenskomst, og samtidig peges der også på, hvordan den islandske fagbevægelse aktivt har støttet oprettelsen af uddannelsescentre i yderområderne, særligt med henblik på at skabe lokalt forankrede muligheder for efter- og videreuddannelse.

- Et andet tiltag findes i Norge, med projektet Menn i Helse, der vedrører omskoling af mænd fra typiske "mandefag" til at varetage jobs i omsorgssektoren. Dette projekt har været ganske succesfuldt, hvis der ses på dels hvor mange mænd, der har taget en sundhedsfaglig uddannelse, og dels at de har fundet beskæftigelse efterfølgende. Via målrettede rekrutteringskampagner og brug af rollemodeller har dette projekt bidraget til at ændre imaget for jobs i omsorgssektoren, og understreget, at dette også er en sektor med jobs til mænd.

- I Danmark er der erfaring med at arbejde med sociale klausuler for at sikre, at der skabes beskæftigelsesmuligheder for lokalbefolkningen i forbindelse med offentlige bygge- og anlægsprojekter. Dvs. at virksomhederne får at vide, at hvis de ønsker at vinde en kontrakt på $\mathrm{fx}$ et offentligt byggeri, skal de $\mathrm{fx}$ tilbyde lærepladser til lokale unge i forbindelse med opgaven.

\subsection{Tema: Kvinder finder livet i yderområderne mindre attraktivt}

Problemstilling: Kvinderne $i$ yderområderne efterspørger flere uddannelses- og arbejdsmuligheder samt et bredere kultur/fritidstilbud. 
De efterspørger også mindre social kontrol og en frisættelse fra traditionelle kønsnormer.

Forskningen på området viser jf. tidligere, at det for ungdommen, især for kvinderne, særligt er uddannelses- og arbejdsmulighederne, der forklarer, hvorfor de ønsker at flytte væk. Dette peger på vigtigheden af, at der arbejdes på at kunne udbyde mere varierede muligheder og arbejdsformer i yderområderne. Kortlægningen af litteraturen vedr. udviklingstendenser på arbejdsmarkederne i yderområderne understreger jf. ovenfor, at en vigtig nøgle til at skabe forandringer i uddannelsesmønstrene og befolkningsstrømningerne, kan ligge i at bløde op for forestillinger om "mandejobs" og "kvindejobs". Hvis de lokale arbejdsmarkeder kan afmontere disse skel, ville det dels udvide udbuddet af oplevede job- og uddannelsesmuligheder for såvel unge mænd som kvinder, og dels medvirke til at skabe det opgør med traditionelle kønsnormer, som de unge kvinder ellers opsøger via deres flytning til større lokaliteter.

En anden tematik relaterer sig til, at de unge kvinder i yderområderne jf. tidligere ofte oplever at have færre muligheder end de unge mænd, når det kommer til typen og graden af foreningsliv, fritidsaktiviteter og kulturelle udbud. Akkurat dette spiller også en vigtig rolle i de unges valg om enten at blive i yderområderne eller at flytte - og her peger litteraturen som beskrevet på, at de aktiviteter, som de unge mænd deltager i, synes at knytte dem mere til stedet, end de aktiviteter, som de unge kvinder deltager i. Samtidig peger forskning fra bl.a. Danmark, Færøerne og Island på, at det for visse unge kvinder også er et led i deres valg om at flytte, at de gerne vil væk fra eksisterende traditionelle kønsnormer, som de finder begrænsende. Kvindernes bevæggrunde for at flytte fra yderområderne omhandler desuden ikke kun uddannelse og jobs, men også at kvinderne føler, at de ikke har mulighed for at påvirke lokalsamfundet og de lokale beslutningsprocesser.

Mulige indsatsområder: Det er vigtigt at kunne udbyde mere varierede muligheder og arbejdsformer i yderområderne. Bredere kulturudbud bør medtænkes, og der bør arbejdes bevidst med at diskutere kønsnormer. Der mangler forskning om, hvilke uskrevne regler og normer, der regulerer relationerne mellem mænd og kvinder i yderområderne.

Det er vigtigt at medtænke hele paletten af livet i de små lokaliteter og bl.a. arbejde bevidst for et bredere kulturudbud og en aktiv diskussion af kønsnormer og forventninger. I forbindelse med udarbejdelsen af kortlægningen, lykkedes det ikke at finde nogle praksiseksempler, der direkte vedrører dette problem. Der var heller ikke i den tværnordiske dialog eksempler på indsatser indenfor dette 
område, men det fremgår, at der fx i Åland peges på et kønsopdelt fritidsliv i rapporter fra Ålands Statiske Bureau, og at forskning fra såvel Grønland som Færøerne peger på, hvordan kulturlivet spiller en rolle for kvinders bosætningspræferencer.

\subsubsection{Konkrete indspil vedr. at få kvinderne til at finde livet i yderområderne mere attraktivt}

- Der bør arbejdes lokalt med at skabe nye fortællinger om yderområderne som steder der rummer relevante muligheder for såvel kvinder som mænd. Det er derfor vigtigt at bryde med de "billeder", som børn og unge præsenteres for i forhold til kønnede valg af hobbyer og fritidsinteresser allerede på et tidligt tidspunkt i uddannelsessystemet.

- Forskning fra især Færøerne og Grønland har peget på, at det kan være et problem at mange lokalråd og kommunale organer ikke har kvindelige medlemmer eller kun ganske få kvindelige medlemmer. Dette kan være medvirkende til at kvinderne føler, at de ikke kan påvirke lokalsamfundene.

- Det er også relevant at medtænke køn i forhold til fritidsaktiviteter og kulturtilbud. Der er forskel på hvilke fritidsaktiviteter og kulturtilbud, der udbydes i byerne og i yderområderne, og ligeledes at disse har en kønsdimension. Når kultur- og fritidsrettede aktiviteter planlægges i yderområderne, er køn derfor et væsentligt aspekt at inddrage. Her kan gender mainstreaming anvendes som en metode til at undersøge forskelle. Helt konkret bør regionale, kommunale og lokale aktører indenfor fritidsudbud og kulturliv overveje hvordan deres tilbud appellerer til hhv. mænd og kvinder, piger og drenge.

\subsubsection{Praksiseksempler vedr. at få kvinderne til at finde livet i yderområderne mere attraktivt}

- Igennem årene har man på forskellig vis i hele Norden arbejdet på at nedbryde det kønsopdelte arbejdsmarked bl.a. med fokus på at få flere kvinder i mandefag og mænd i kvindefag. I den tværnordiske dialog blev det fremhævet, at erfaringer fra Norge viser, at den enkønnede struktur har en tendens til at reproducere sig selv, så snart fokus fjernes. Det blev beskrevet, at myndighederne i Norge i en periode satte stor fokus på at få kvinder ind i mandefagene, hvor der samtidig indgik en masse frivillige, som fungerede som rollemodeller. Initiativet 
havde stor effekt og rykkede på både det kønsopdelte uddannelsesvalg og arbejdsmarkedet. Konklusionen på projektet var, at det er muligt at rykke på de traditionelle kønsopdelte valg af både uddannelse og job, og at nationale/regionale/kommunale initiativer har en effekt - men det kræver en stor indsats samt en kontinuitet $i$ indsatsen.

\subsection{Tema: Arbejdsudbuddet er for snævert i yderområderne}

Problemstilling: Manglen på jobs, der matcher deres kvalifikationer, får især kvinderne til at forlade yderområderne.

Arbejdsudbuddet er ofte meget snævert i yderområderne med få jobs i den tertiære sektor (dvs. indenfor handel og service) og særligt få jobs indenfor vidensbaseret arbejde, der typisk fordrer en højere uddannelse. Da der generelt i hele Norden er en situation, hvor flere unge kvinder end unge mænd tager en universitetsuddannelse, betyder dette at arbejdsmarkederne i yderområderne ofte simpelthen ikke rummer jobs, der matcher kvindernes kvalifikationer, hvilket får dem til at fravælge disse områder.

Mulige indsatsområder: Decentralisering af offentlige vidensarbejdspladser, støtte til iværksætteri, oprettelse af "SMART-work" centre.

Det er vigtigt, at der arbejdes på at diversificere arbejdsudbuddet $\mathrm{i}$ yderområderne, dvs. skabe arbejdspladser der ikke ligner dem, der allerede findes lokalt. Forskning peger på, at det ikke er stedets størrelse med derimod dets interne variation i arbejdsudbuddet der er den udslagsgivende faktor for om der opstår et "kvindeunderskud" eller ej (se fx Hamilton og Otterstad 1998). I denne proces er det væsentligt, at der etableres arbejdspladser til højtuddannede i lokalområderne og/eller at mulighederne for fjernarbejderpladser styrkes, da kvinderne i højere grad end mændene har en længere videregående uddannelse.

\subsubsection{Konkrete indspil vedr. at gøre arbejdsudbuddet bredere i yderområderne}

- I den tværnordiske dialog påpegede en repræsentant fra det Færøske Universitet, at problematikken omkring "kvindeflugten" konkret kunne imødegås ved at de enkelte nordiske lande udvikler en "mobilitetspolitik". Dette ville muliggøre, at man fx bor i Tórshavn, men arbejder i København eller Reykjavik. På Færøerne er 
der allerede folk, som lever og arbejder på denne måde, men det er vanskelig med det nuværende system - særligt i forhold at udbrede det til forskellige sektorer, fx skal man være håndværker for at kunne få befordringsfradrag under de gældende regler. Det blev foreslået at dette kunne være et politikområde, som man kunne adressere samlet på et nordisk plan, for derved at lette mulighederne for at bo i yderområderne og samtidig have et spændende og relevant arbejde.

- Der kunne ses på mulighederne for at forbedre de infrastrukturelle vilkår for at starte virksomhed og/eller arbejde fra en lokal base - $\mathrm{fx}$ ved hjælp af hurtigt bredbånd og kontorfællesskaber.

\subsubsection{Praksiseksempler vedr. at gøre arbejdsudbuddet bredere i yderområderne}

- Et eksempel til mulig kopiering i andre kontekster er erfaringer med støtte til iværksætterkurser. Disse findes generelt i flere nordiske lande, eksempelvis Brautargengi som er et islandsk projekt specielt målrettet kvindelige entreprenører. Kurset har været medvirkende til at styrke unge kvinders bevidsthed om mulighederne for at starte egen virksomhed som en alternativ karrierevej - også i yderområderne. Dermed har projektet været medvirkende til at fastholde nogle kvinder i yderområderne, som ellers ville have søgt mod de større byer for at finde beskæftigelse.

- SMART work centre findes flere steder i Norden, men ofte i urbane områder, skønt der er stort potentiale også udenfor de større byer. Et eksempel på dette findes fx i Fjernarbejderhuset i Tranum i Danmark, der bl.a. er oprettet under et motto om Tranum som "Europas hurtigste landsby".

\subsection{Tema: Yderområdernes stigma påvirker de unge af begge køn}

Problemstilling: Den negative omtale af yderområderne forstærker de unges ønsker om at flytte væk.

Af kortlægningen og den tværnordiske dialog fremgår det jf. tidligere, at der findes forskellige negative forestillinger om og italesættelser af de nordiske yderområder, og de mennesker, som bor her. Dette negative stigma er ikke kun forankret i medierne; det høres også jævnligt blandt politikere, praktikere, forskere og ikke mindst registreres det hos de 
mennesker, især de unge, der bor i yderområderne. Indenfor forskningen tales der her om såkaldte overlokale strømninger; herunder bl.a. billeder af hvad der kendetegner "det gode liv" og fortællinger knyttet til yderområderne, og som fremføres i både trykte, digitale og sociale medier og på nettet i øvrigt. Netop internettet og de sociale medier er vigtige arenaer i de unges daglige liv, og de udgør for mange unge også i yderområderne en vigtig referenceramme for den måde, hvorpå de ser sig selv, og de tanker de gør sig om fremtiden (Faber, Pristed Nielsen \& Bennike 2015).

Yderområdernes stigma påvirker både de unge piger og drenge, og den negative omtale af yderområderne forstærker de unges ønsker om at flytte væk. I den tværnordiske dialog blev det bekræftet, at der i yderområderne på tværs af Norden nærmest opstår en fortælling om at det er "nødvendigt" at flytte væk for at være "moderne". Den negative fortælling om de nordiske yderområder indikerer, at de opfattes som steder, der må forandres (moderniseres), snarere end steder, der skal næres og bevares. Her peger forskningen på, at den opfattelse, som de unge får af yderområderne, er vigtigere end de faktiske forhold. I den tværnordiske dialog og erfaringsudveksling blev det understreget, at man ved at fremme andre billeder og muligheder kan medvirke til, at nye mønstre og strategier udvikles blandt de unge, og måske især mændene, i yderområderne.

Mulige indsatsområder: Der er behov for nye fortællinger om yderområderne: fortællinger om yderområderne som steder, der skal næres og bevares. Forskningen peger på, at nogle (særligt mænd) vælger at blive boende i yderområderne, fordi de trives her.

Det er nødvendigt at nuancere fortællingerne om livet i yderområderne, og vigtigt at huske på, at nogle (mænd) aktivt vælger at blive, fordi de trives netop her, og at det derfor også er vigtigt at undgå at skabe en fortælling om, at den eneste vej frem for de unge er at rejse væk for at få sig en uddannelse og et job. Det er derfor vigtigt, at stigmatiseringen af yderområderne bliver italesat, således at der kan ske en holdningsændring. Dette er dog en langsigtet proces og det er derfor vigtigt, at der er politisk opbakning til at styrke yderområderne, hvilket inkluderer, at der tages stilling til infrastruktur, fritidstilbud, internet, dagsinstitutioner, sociale institutioner og decentralisering af alle velfærdstilbud, osv. Samtidig er det vigtigt at fremhæve rollemodeller, der kan italesætte gode eksempler. Her har skolen og lærerne en vigtig opgave $i$ at have et blik for det enkelte barn/den enkelt unge og ikke blindt videreformidle eksisterende kønsnormer og forventninger. Derudover har yderområderne et ansvar for også selv at 
tale tingene op og fremhæve fordelene ved at være bosat i mindre kommuner/områder både i forhold til fritidsliv og arbejdsliv.

I den tværnordiske dialog blev det bl.a. italesat, at der politisk i løbet af de sidste tyve år er sket et skifte i forhold til arbejdet med regional udvikling fx i Sverige. Det er et skifte, som den gennemførte kortlægning bekræfter også kan identificeres i mange af de andre nordiske lande - om end Norge her adskiller sig med en mere decentral tilgang. Pointen er, at hvor der tidligere på nationalt plan i de enkelte nordiske lande var et stærkt fokus på statsligt at sikre lige muligheder og lige levevilkår i alle områder, synes der at være sket en drejning, således at fokus på tværs af Norden - selvom vækst i alle områder fortsat tematiseres - ofte alligevel udmønter sig i en tydelig prioritering af storbysregionerne og de bynære områder.

\subsubsection{Konkrete indspil vedr. at skabe en ny fortælling om yderområderne}

- Kortlægningen og den tværnordiske dialog peger på, at indsatsen på alle niveauer (nationalt, regionalt og lokalt) i højere grad skal rettes mod at ændre fortællingen om Nordens yderområder, således at andre billeder og muligheder fremmes for på den måde at medvirke til, at nye mønstre og strategier for begge køn udvikles.

\subsubsection{Praksiseksempler vedr. at skabe en ny fortælling om yderområderne}

- Et tydeligt eksempel på en succesfuld "ny fortælling" blev præsenteret som en del af den tværnordiske dialog. En repræsentant for Ærø Kommune i Danmark berettede således om et initiativ, som er lanceret for at øge bosætningen på øen, herunder specifikt ideen om etablering af et såkaldt "bosætningshus", hvor personer eller familier der overvejer at flytte til øen kan søge om at få lov at bo i op til $3 \mathrm{mdr}$. for at "prøve ø-livet af" uden at binde sig ved at investere i en bolig fra første dag. Både på Ærø og ved lignende andre tiltag $\mathrm{i}$ Denmark har man også arrangeret møder, hvor "nye" og "gamle" beboere kan møde hinanden.

- Både i Sverige og Danmark er der dannet interesseorganisationer, der i fællesskab forsøger at varetage interesserne for nogle at de mindre tæt befolkede egne. Foreningen Hele Sverige Ska Leva samt Sammenslutningen af Danske Småøer var således repræsenteret i den tværnordiske dialog og her blev der berettet om bl.a. 
brandingstrategier og forsøg på at skabe fælles (lokal)politiske løsninger på nogle af udfordringerne.

- Uddannelsen West Nordic Master er et eksempel på en uddannelse, der udbydes i samarbejde mellem universiteter i Færøerne, Island, Nord-Norge og Grønland. Denne uddannelse fokuserer i sit indhold specifikt på de udfordringer de nordiske yderområder står overfor, herunder også kønsdimensionerne af disse udfordringer.

- Også i forhold til initiativer og projekter, der sigter mod at gøre yderområderne mere attraktive og dermed tiltrække tilflyttere er det relevant at medtænke et kønsperspektiv. Et eksempel herpå er fx Tiltakssonen i Finnmark og Nord-Troms i Norge. Dette projekt indebærer studielånsaflastning eller -eftergivelse for højtuddannede, der bosætter sig i Finnmark og Nord-Troms efter endt uddannelse (da flere kvinder har en uddannelse og dermed et lån har dette tiltag en iboende kønsdimension). Projektet omfatter også højere børneydelse og løntillæg til dagsinstitutionspersonale i yderområderne (dette vedrører begge forældre, men forskning viser at særligt kvinder vægter kvaliteten af velfærdsudbuddene, når de tager beslutning om, hvor de vil bosætte sig). 



\section{Referencer}

Baagøe Nielsen, S. (2011). Nordiske mænd til omsorgsarbejde!: - en forskningsbaseret erfaringsopsamling på initiativer til at rekruttere, uddanne og fastholde mænd efter finanskrisen. Roskilde: VELPRO - Center for Velfærd, Profession og Hverdagsliv.

Bjarnason, T., \& Thorlindsson, T. (2006). Should I stay or should I go? Migration expectations among youth in Icelandic fishing and farming communities. Journal of Rural Studies 22 (3): 290-300. doi:10.1016/j.jrurstud.2005.09.004

Bloksgaard, L., Faber, S. T., \& Hansen, C. D. (2013). Drenge i Udkanten - Køn, Stedtilknytning og Uddannelse. I: C. H. Jørgensen (red.), Drenge og maskuliniteter $i$ ungdomsuddannelserne (1. udg., 87-208). Roskilde Universitetsforlag.

Dahlström, M. (1996). Young women in a male periphery - Experiences from the Scandinavian north. Journal of Rural Studies 12 (3): 259-71. http://dx.doi.org/ 10.1016/0743-0167(96)00018-6

Faber, S. T., Nielsen, H. P. \& Bennike, K. B. (2015). Sted, (U)lighed og Køn - En kortlægning af udfordringer og best practices i relation til køn, uddannelse og befolkningsstrømme i Nordens yderområder. TemaNord, 2015:557. København: Nordisk Ministerråd. http://dx.doi.org/10.6027/TN2015-557

Gaini, F. (2006). Once Were Men. Maculinities among young men in the Faroe Islands. In: Fróðskaparrit 54 [Annales Societatis Scientiarum Færoensis]. Torshavn: Faroese University Press.

Giskeødegård, M. F. \& Grimsrud, G. M. (2014). Kjønnsperspektiv på rekruttering av innbyggjarar til Møre og Romsdal. Rapport 52. Møreforskning, Højskulen i Volda, Møre og Romsdal Fylkeskommune.

Haagensen, K. M. (2014). Nordic Statistical Yearbook 2014. Vol. 52. Copenhagen: Statistics Denmark - Nordic Council of Ministers. http://dx.doi.org/10.6027/ Nord2014-001

Hamilton, L. C., \& Otterstad O. (1998). Sex Ratio and Community Size: Notes from the Northern Atlantic. Population and Environment 20 (1): 11-22.

http://dx.doi.org/10.1023/A:1023347817418

Helvé, H. (red.). (2003). Ung i Utkant - Aktuel forskning i glesbygdsungdomar. København: Nordisk Ministerråd.

Hovgaard, G., Eythórsson, G. T., \& Fellman, K. (2004). Future Challenges to Small Municipalities: The Cases of Iceland, Faroe Islands and Åland Islands. Stockholm: Nordregio, Nordic Centre for Spatial Development.

McDowell, L. (2003). Redundant Masculinities? Employment change and white working class youth. Oxford: Blackwell Publishing.

Paulgaard, G. (2012). Geography of opportunity. Approaching adulthood at the margins of the northern European periphery. I: U.-D. Karlsen Bæck \& G. Paulgaard (red.) Rural futures?: finding one's place within changing labour markets (s. 189216). Stamsund: Orkana Akademisk.

Paulgaard, G. (2015). Place Attachment, Unemployment and Masculinity: Young Men in the High North. I: S. T Faber \& H. P. Nielsen, Remapping Gender, Place and Mobility - Global Confluences and Local Particularities in Nordic Peripheries (s. 207-20). Farnham: Ashgate Publishing. 
Rafnsdóttir, G. L. (red.). 2010. Kvinder og Velfærd i Vestnorden. TemaNord 2010:578. København: Nordisk Ministerråd. http://dx.doi.org/10.6027/TN2010-578

Rasmussen, R. O. (red.) (2010). Mobilitet i Grønland: Sammenfattende analyse. Stokholm: NordRegio.

Ravenstein, E. G. (1885). The Laws of Migration. Journal of Statistical Society, $n r$. 48: 167-227.

Rönnblom, M. (2005). Letting Women in? Gender Mainstreaming in Regional Policies. NORA - Nordic Journal of Feminist and Gender Research 13 (3): 164-74. http://dx.doi.org/10.1080/08038740600587711

Siim, B. \& Stoltz, P. (2015). Particularities of the Nordic: Challenges to Equality Politics in a Globalized World. I: S. T. Faber \& H. P. Nielsen, Remapping Gender, Place and Mobility - Global Confluences and Local Particularities in Nordic Peripheries, (s. 19-35). Farnham: Ashgate Publishing.

Stenbacka, S. (2011). Othering the rural: About the construction of rural masculinities and the unspoken urban hegemonic ideal in Swedish media. Journal of Rural Studies 27 (3): 235-44. http://dx.doi.org/10.1016/j.jrurstud.2011.05.006

Weyhe, T. (2011). Finanskrisen og arbejdsmarkedet i Grønland. I: Baagøe Nielsen, S., Nordiske mænd til omsorgsarbejde!: - en forskningsbaseret erfaringsopsamling på initiativer til at rekruttere, uddanne og fastholde mænd efter finanskrisen. Roskilde: VELPRO - Center for Velfærd, Profession og Hverdagsliv.

Ålands statistik och utredningsbyrå (2013). Kvinnors Och Mans Val Och Villkor I Samhalle Och Arbetsliv. Publiceras Som Bilaga till Landskapsbudgeten 2013. 


\section{Résumé - UK}

During the Danish Presidency for the Nordic Council of Ministers in 2015, attention was drawn towards challenges and best practice examples in relation to gender, education and population flows in peripheral areas throughout the Nordic countries - Norway, Denmark, Sweden, Finland, Iceland and the autonomous countries, Greenland, the Faroe Islands and Aaland. This report briefly summarises the findings covered in existing Nordic research and literature within the field, and further presents the experience and professional responses, which were presented during a knowledge-sharing seminar for different stakeholders across the Nordic countries. Thus, the report provides a condensed presentation of the knowledge available within the field, while also providing a more practical source of inspiration for policymakers, other authorities and actors with respect to future actions in this area - locally, regionally, nationally and across the Nordic region. 
Nordisk Ministerråd

Ved Stranden 18

DK-1061 København K

www.norden.org

\section{Køn, uddannelse og befolkningsstrømme}

Under det danske formandskab for Nordisk Ministerråd blev der i 2015 sat fokus på udfordringer og gode praksiseksempler i relation til køn, uddannelse og befolkningsstrømme i yderområderne i hele Norden - Norge, Danmark, Sverige, Finland, Island og de selvstyrende lande Grønland, Færøerne samt Åland.

Denne opsamlingsrapport sammenfatter de resultater samt konklusioner, som er afdækket i den eksisterende nordiske forskning og faglitteratur på området samt de erfaringer og faglige indspil, som er kommet frem undervejs i den fælles dialog og erfaringsudveksling. 